\title{
More Private Schools for Nonnative Students? Migrant Performance in Private Schools of Differing National Contexts
}

\author{
Monika Jungbauer-Gans ${ }^{1}$ and Christiane Gross ${ }^{2}$ \\ ${ }^{1}$ University of Erlangen-Nuremberg, Findelgasse 7/9, 90402 Nuremberg, Germany \\ ${ }^{2}$ Institute of Social Sciences, University of Kiel, Westring 400, 24098 Kiel, Germany \\ Correspondence should be addressed to Monika Jungbauer-Gans, monika.jungbauer-gans@wiso.uni-erlangen.de
}

Received 30 August 2010; Revised 17 January 2011; Accepted 23 February 2011

Academic Editor: Wayne Martino

Copyright (C) 2011 M. Jungbauer-Gans and C. Gross. This is an open access article distributed under the Creative Commons Attribution License, which permits unrestricted use, distribution, and reproduction in any medium, provided the original work is properly cited.

\begin{abstract}
Migrant children from most countries are disadvantaged in school. We investigate which characteristics of both school and societal contexts influence the achievements of migrant students. We argue that living conditions and inequality in a society as a whole may affect the chances of minority members and the function that private schools perform in the process of social reproduction of inequality. We investigate in particular the question of whether migrant students attending private schools show a better performance than those attending public schools. The analyses of the paper are based on the data collected in the PISA 2006 survey. Our main results are that the lower mathematics and reading competencies of migrant students can partly be explained by the socioeconomic status and cultural capital of the family and-to a marginal degree-by school characteristics. Initially, students in private independent schools have some advantages that disappear after controlling for country attributes. In both fields of knowledge, migrants obtain better results in private government-dependent schools (interaction effect); this, however, can be traced back to their families' socioeconomic origin and cultural capital. We detect that students in private independent schools reach lower competency levels in wealthier societies (GNP).
\end{abstract}

\section{Introduction}

Educational disparities between migrants and native students (and between different ethnicities in the same country) have been identified by several studies [1-3]. Why are the disadvantages of migrant children so problematic? The chances of economic development under the condition of a globalizing economy depend heavily on the level of education and human capital in a given country. Education is of high importance for technological innovation and scientific development in a society. Labor market data show that those individuals without tertiary education or vocational training suffer from high rates of unemployment $[4,5]$. Education improves the chances of individuals in the labor market. By furthering economic development, human capital reduces the financial burdens on society of welfare or unemployment benefits. In combination with low fertility rates, industrialized countries are urged to integrate migrants into their domestic labor market as far as possible. Besides that, it is a matter of social justice not to discriminate against specific groups. Common cultural experience acquired in school seems to be important for social cohesion, for example, social and political participation [6]. For migrant adolescents, education might influence their economic, civic, and political trajectories into adulthood, their modes of acculturation and ethnic identity formation, as well as their pattern of language use [7]. Returns to education can be found in almost all spheres of life concerning not only chances in the labor market, but also fertility and family formation, health and mortality rates, to name just a few [8].

Some of the disadvantages of migrant students in the educational system might be explained by family factors such as socioeconomic status and cultural capital. Is the school context the source and precondition of inequality in achievement between migrant and native-born students? In search of causes for the ethnic variations in students' 
achievements, the renowned Coleman report [9] has already underlined the immense importance of the class context and its ethnic composition. In our multilevel study, we will investigate which characteristics of the school context influence the achievements of students in general and of minority students in particular. The characteristics considered in our paper are the ethnic, gender, and socioeconomic compositions of schools. Beyond that, we investigate in particular the question of whether or not attending a private school could lead to better performance by migrant students.

"Private schools are better"-this has been a widely held belief since Coleman and his collaborators $[10,11]$ published their famous study on achievement in public and private schools in 1982. In terms of socioeconomic background, minority status, low test scores, or disciplinary problems, the most disadvantaged students are likely to profit from attending private Catholic schools [12]. One of the explanations they used to clarify their results is that private Catholic schools can rely on more social capital [13]. Closed and dense social networks between parents and teachers can be found in Catholic private schools. Parents who choose to enroll their children in Catholic schools might value the quality of the school and the moral education provided [14]. Since these schools have, like most other private schools, lower levels of funding than do public schools and also face competition with other schools, they tend to spend the money in a manner that promotes school quality. Students whose achievements in most public schools would relegate them to a general or vocational track are more likely to be placed by Catholic schools on an academic track, where more advanced coursework and homework is demanded of them [12]. This may lead to a school climate where all students, and especially students form disadvantaged backgrounds, are encouraged to learn. In a further step, we argue that living conditions and inequality in a society as a whole may influence the chances of minority members and the function that private schooling performs in the process of social reproduction of inequality.

In this paper, we enhance the discussion on school achievement by integrating three levels of determinants. Controlling for the socioeconomic status and cultural capital of families at the individual level, we investigate migrant students' competencies, both in different school contexts and within national conditions of wealth and economic inequality. From here, we draw analogies between research on students with low socioeconomic background and the situation of migrant students. We add further to the discussion by arguing that the average wealth of a society indicates high levels of human capital in the population as well as a high need for education for labor market entry of young generations. Additionally, we argue that high inequality indicates low levels of redistribution via taxation and social welfare systems [15] at the same time as little room or resource for public investment in the education system. Under these conditions, in order to acquire human capital, national elites finance private institutions or send their children to schools and universities abroad.
We use data from the PISA 2006 survey conducted by the OECD in 57 countries. Mathematics and reading competencies serve as indicators of school performance. Since mathematics competencies are less dependent on language skills than are reading abilities, we think that both should be looked at when investigating performance differences between native and migrant children. Competencies in general are an important return to educational processes and should correlate highly to school grades, graduation levels (secondary or tertiary education), and further labor market outcomes such as prestige or income. To operationalize migration status, we do not use the birth countries of children and parents but rather the language used at home. This proxy of migration status seems more useful in terms of educational achievement because of the relevance of the command of language for learning. Additionally, the populations of migrants differ considerably in the countries of destination depending on geographic proximity to countries of origin, migration policy in the course of time, economic disparities between country of origin and destination, attractiveness for top professionals, and processes of community and network formation among migrant populations such as Chinatowns. A migration status of first or second, generation might have different implications in different destination countries. A study analyzing first, second and third (or further) generations of migrants found that more recent immigration lowers educational achievement [7]; however, if both parents are born abroad, the chances of attending college are higher than if only one parent is born abroad.

In the following, we summarize the state of research concerning the scholastic achievements of migrants. Combining this with the results from the research on private schools, we conclude that some characteristics of private schools may lead to schooling contexts that help those students with migratory backgrounds. In Section 2, we describe data and methods before presenting and discussing the results from our investigations.

\section{Theoretical Background}

2.1. Migrant and Ethnic Minority Children in the Education System. When dealing with minority students, some overlapping but not equivalent criteria must be considered. A possible indicator of minority status is ethnicity. In most cases, ethnic minorities belong to groups that migrated from abroad to a country of destination, but there are also examples of ethnic minorities having lived within a country for generations. The second criterion aims at the migration process itself focusing on the movement from one country to another. Migrants in most cases belong to ethnic groups that form minorities in the receiving country, but who may, also, join the majority, since they were repatriates who (either recently or whose ancestors even hundreds of years ago) left their country of origin. Additionally, language makes the situation even more complicated; migrants can be divided into groups who used the language of the receiving country prior to migration and those who did not. When summarizing the state of research in the following, we use results from studies dealing with ethnic minorities as well 
as with migrants. In most cases, the mechanisms influencing their situation in the education system do not differ.

Do migrant and native children differ in their educational achievements? Most of the empirical studies on this topic conclude that migrant or ethnic minority students have lower achievements at school or college. A smaller proportion of migrants is assigned to academic tracks [16, 17]. Reading, mathematics, and science competencies for those students with both parents born outside the country are lower on average (PISA 2000, [18]; similar in PISA 2000E, [19]; in PISA 2003, [20, 21]; or PISA 2006, [22]). Secondgeneration migrants have a higher chance of finishing school at upper secondary level than children born abroad [23]. A panel study of a subsample of PISA 2003 in Germany shows that the percentage of migrants is higher in the 9th grade than one year later because of higher dropout rates [24]. This means that in terms of abilities or need for achievement, a positively selected group remains in education. The increase in competencies after one year is largest among migrants followed by students with one parent born in Germany. The increase in competencies is smallest among secondgeneration migrants born in Germany. The older children are at the time of migration, the poorer are their chances $[3,23,25]$.

Several studies compare the educational chances of ethnic minorities from different regions of origin within different receiving countries [26-34]. They can show that not all groups are disadvantaged but that some groups of migrants in a number of receiving countries outperform native-born children (e.g., people from India in Norway [31], England and Wales [33], or from Greece or the former Soviet Union in Germany $[35,36])$.

Which mechanisms explain the differences between native-born and migrant young people? We distinguish between determinants relating to individuals, that is, parents and children, and those relating to schools or to the national context. Determinants on the individual level are cultural, and socioeconomic factors. Theoretical explanations argue that the financial, cultural and social resources of parents improve educational performance [37]. In most cases, the socioeconomic status of migrants is lower than that of the native population. This is especially the case where countries have had in place migration policies that attracted less qualified people. There is also a considerable group of highly educated or top professionals among migrants. In relation to their country of origin, migrants may be a positively selected group with respect to ambitions and flexibility [28]. In the US, however, migrant blacks are less able than native students to translate their parents' education into high grades [38]. Additionally, there are some doubts as to whether the current socioeconomic status of parents really reflects their educational resources. Because grades received in the country of origin might not be acknowledged, the education received in the country of origin is in many cases higher than the socioeconomic status achieved in the country of destination [39]. After controlling for education, socioeconomic status, and parental income, the disadvantages among most ethnic minority students disappear, and in some cases, even better chances can be seen among ethnic groups than for the natives population $[18,35,36,40]$. With only a few exceptions, controlling for the socioeconomic status of parents removes or considerably reduces differences in educational success between migrants and native students (e.g., [33] for England and Wales; [32] for the US; [31] for Norway; [30] for Belgium; [28] for France). As with social class, the educational aspirations of migrants are lower on average than of native students, but several examples of groups with high ambitions are reported in the literature. These empirical studies find evidence that strong emphasis on education is a highly significant correlate of achievement among adolescents from migrant families [41-43].

Another explanation for disadvantages is the migrants' lack of strategic knowledge of the education system [3, 37, 44]. Cultural factors leading to migrant disadvantages are as follows: when the language at home differs from the language used at school [45], this may result in a disadvantage throughout the whole of the student's education [23]; parents who do not master the language at school can hardly support their children in doing homework [3]. However, deficits in the learning culture could not be confirmed in a study analyzing the feelings of marginalization, or problems with parents because of their traditional attitudes or poor command of language [6]. Some groups, for example, workers who came to industrialized countries in the $1960 \mathrm{~s}$ and 1970s ("Gastarbeiter"), may have working class habits that correlate with low educational aspirations.

A second group of determinants of the disadvantages of minority members can be found at the school level. In the US, schools seem to enhance disparities in the achievements of African American and white students, while at the same time slowing the growth of social class differences [46]. Class composition influences children's chances: the more minority members in a class, the lower the rate of students among those who select academic tracks (see [2]; however, Walter [24] does not find this result). One reason may be that segregation in preschool and primary school reduces the chances of learning the language of the destination country [3, 47, 48], and thus reduces reading literacy [49]. Stanat [50] concludes that only in the case where a class is made up of more than $40 \%$ migrants, a negative effect on reading literacy can be found. In the US, many studies analyze the educational success of ethnic groups. Portes and Hao [51] show that Asian Americans have better grades and Mexican Americans worse grades than European Americans. Having a higher proportion of the minority group within a school reduces the differences between those groups. School segregation as a phenomenon resulting from housing segregation may be intensified by parental choice of schools, especially if schools compete for students by special pedagogical profiles [52]. Political decisions to tailor school districts according to socially stratified neighborhoods sometimes reinforce school segregation. However, if there are schools that use the language of the migrants (e.g., Greek secondary schools in Germany), the respective ethnic group shows even higher rates of high school graduates than the majority [23]. There is some discussion whether ability grouping affects the achievement of migrant students thus exacerbating 
inequality of achievement $[53,54]$. Ability grouping itself is correlated to lower achievement [55]. International research has shown that stereotypes influence the perception and evaluation of information [56-58]. Stereotypes towards ethnic groups are often correlated to expectations regarding intelligence and abilities (see overviews in $[53,59,60]$ ). Teachers' perceptions and stereotypical images of ethnic groups might be another source of disadvantage, since threat of stereotyping may undercut the achievement of minority students [34]. When migrants are forced because of their poor command of language to go to types of schools with low demands, this could lead to an accumulation of disadvantages. Farley [61] argues that cultural differences might explain the problems of minority students. If their cultural background is not represented in school materials, this may harm the self-image and self-esteem of minority students [62]. Additionally, there are only a few teachers with a migration background of their own who could serve as a role model.

A third group of determinants is to be found at the level of countries. If a traditional migrant-receiving country has strict migration laws, migrants' children have better educational performance [63]. Whereas children who have emigrated from countries with a high level of economic development perform more poorly, those from more politically stable countries perform better at school. Education systems in the country of destination differ in a number of ways including amount of stratification at the lower secondary level, amount of time spent at school each day, teacher training (especially at preschool and primary school levels), governance of the education system, and treatment of children with a migration background or those coming from a disadvantaged social group. The earlier in a student's education that differentiation and stratification into different tracks takes place, the more influence parents have and the more important is the socioeconomic and ethnic origin for school achievement [64]. Ethnic inequalities are higher when comprehensive schooling is shorter in duration [45], however, comprehensive school systems may be detrimental to the educational success of migrants if neighborhood segregation is high. This effect is more problematic in societies with high levels of inequality. The higher the amount of time spent at school, the lesser is the extent of parental care and thus the influence of socioeconomic and ethnic origin on achievement is lower. The earlier young children attend kindergarten and preschool, the more possibility teachers have to compensate for disadvantages (e.g., the command of language of migrants). Teacher training seems to be relevant, since academic training may include theoretical pedagogical knowledge helpful for teachers meeting the challenge of advancing socially disadvantaged students. Governance by evaluation and accounting (governance by output) may lead to more effort in reducing disadvantages of social origin in order to obtain better results. In contrast, governance by curricula and statutory regulation (governance by input) does not give much incentive to further disadvantaged groups. If there are systematic programs to promote disadvantaged groups, such as the Migrant Education Program in the US or the "zones d'éducation prioritaires" (ZEP) in France, this might improve the chances of minority members (see for a summary of the research on the effects of characteristics of education systems [65]).

2.2. Private Schools. The American study "High School and Beyond" is the first longitudinal study that compares public and private schools [10, 66]. Coleman [67] summarizes the results: "First, we found evidence of higher academic achievement in basic cognitive skills [...] in Catholic schools than in public schools for students from comparable family backgrounds" [67, page 240]. "Catholic schools appear to be characterized by both higher quality, on the average, and greater equality than public schools" ([67, page 241]; emphasis in original).

The subsequent literature analyzing the differences in effectiveness between public and private schools is sizable (for reviews, see, e.g., $[68,69]$ ). In most cases, they argue that students in private schools display a higher level of performance. Dronkers and Robert [70] summarize the causes for the higher effectiveness of private schools discussed in the literature. (1) Students from a more favorable social background will attend private schools. In most private schools, parents must pay (higher) tuition fees than in public schools, and therefore, some families cannot afford to send their children to private schools. This leads to a composition of students with a higher proportion from families with a higher socioeconomic status than found in public schools. Other studies show that parents with higher education and higher socioeconomic status more often choose private schools [71-73]. In the US, a "native flight" from public to private schools in response to inflows of migrants has been identified [74]. (2) School choice leads to self-selection processes in which private as well as public schools become homogeneous communities with shared values. If comparing the performance of private and public schools, these selection processes and the social mechanisms of school choice must be taken into account. (3) Private schools depend more on student fees and on private charity and, therefore, must form stronger relations between parents and staff, which may partly explain the better performance of students. (4) Social and value-related selection processes, more intense social ties and special pedagogical conceptions in some private schools will contribute to a better school climate affecting teachers' morale and norms of interaction between teachers and students; however, Morgan and Sørensen [75] who do not find higher social capital in Catholic schools criticize the social capital explanation. (5) Private schools have a more limited differentiation in their curriculum due to either smaller school size or school traditions, and thus, we expect that students in private schools perform better. (6) Another explanation is stated by Chubb and Moe [76], who argue that private schools have more autonomy in allocating their resources, selecting their staff and creating the curriculum: "They have clearer goals and stricter requirements, and they put greater stress on academic excellence. [...] Teachers are more involved in policy decisions, have greater control over their work, and are more satisfied with their job." [76, page 378]. 
In the following, we review the results on students' achievements from selected studies using PISA data. It is difficult to draw a clear-cut conclusion, since the studies do (or do not) apply different methodologies to control for the selection bias, for the hierarchical clustering of the data, or the disproportional stratified random sample. Another reason for heterogeneous results is that the studies select different countries for analysis or exclude schools with a low number of students.

Dronkers and Robert [70, 77, 78] differentiate between private independent, private government-dependent, and public schools with PISA 2000 data from 19 countries. They find, after controlling for social composition and school climate, that private government-dependent schools outperform public schools. On the other hand, private independent schools are even less effective than public schools (see Vandenberghe [79] for similar results).

Controlling for student characteristics, family background, country characteristics such as GNP per capita, school resources, teacher education, external exit exams, and school autonomy, Fuchs and Wößmann [80] also used PISA 2000 data. They uncover a lower performance in publicly managed schools for mathematics, science, and reading abilities but a positive effect of the share of government funding on students' performance at least in mathematics (see also Wößmann [81]).

Vandenberghe and Robin [83] compare the results in nine countries using PISA 2000 data and using different methods to control for the selection bias. They find persistent advantages in private schools in three countries, insignificant differences in another three countries, and mainly disadvantages in private schools in the remaining three countries. Paunescu [68] reaches a similar conclusion: in Denmark, the Netherlands, and Japan, higher efficiency was found in public schools, in Belgium, Ireland, and Mexico, no differences after controlling for selection processes and school characteristics were found, and in Spain and France, higher efficiency was found in government-dependent private schools. These results contradict the conclusion of Dronkers and Robert [70] that the private school effects are similar in all the countries studied. This is the reason that we look for the mechanisms that could explain these differences between countries. We include country-level variables in our analyses to describe the societal context of private schools.

Standfest et al. [84] used the PISA 2000 enhanced data set for Germany to investigate whether students in schools operated by churches have higher achievements. The results differ between the types of schools. Only in two nonacademic type schools do they locate achievement-related advantages in private, church-operated schools. Weiß and Preuschoff [85] obtained a similar result. They find that the positive effect is restricted to girls in schools of medium level. Private schools in Germany do not have much higher autonomy, but rather more contact between school and parents and a better school climate. More 15-year-old students attend the 10th grade year, because the proportion of students who had to repeat a level is smaller in private schools. This might be an indicator of a supportive culture in private schools.
Finally, selected results from studies based on other data sets are as follows: using BIJU data for Germany, Dronkers et al. [86] reach the conclusion that pupils in non-public schools have higher cognitive and noncognitive test scores than pupils from public schools. A study in North RhineWestphalia (a part of Germany) concludes that only students in Catholic or Protestant high schools but not in other private schools have better grades in their final exams than students in public schools [87]. Figlio and Stone [88] detect positive effects of private schools with data from the US only, regarding the probability of college attendance or selective college attendance and better mathematics test performance, only for a few distinct subgroups after correcting for selection processes. An international study with data from Latin American countries deduces that students' socioeconomic backgrounds account only for a small portion of higher achievements in private schools, and a substantial portion is explained by varying peer group characteristics [89]. After controlling for peer group characteristics, the private school effect on all countries is consistently zero. This result also was found based on data from Denmark [90].

2.3. Migrant Children in Private Schools. Whether students from lower social strata perform better in private government-dependent or government-independent schools than in public schools is investigated by Corten and Dronkers [91]. They refer to Coleman and Hoffer [66] who find the result that students from lower socioeconomic backgrounds benefit most from private schools (see also [12]). They explain this interaction effect as social capital resulting from functional communities with high network density and consistency of value in private schools. The school climate in these schools provides an atmosphere oriented towards learning; a clear and focused curriculum that is agreed by parents leads to clear expectations from students by both school and parents. These conditions are more often necessary for the success of students from lower socioeconomic strata, while they only marginally enhance the resources of students from higher social strata. Corten and Dronkers [91] see moderate support for the thesis that private government-dependent schools are slightly more effective for students with less cultural capital. Their second hypothesis that lower class students have poorer results in private independent schools is clearly refuted: students with a low socioeconomic background (fathers' occupational status) or a large number of siblings perform better in private independent schools than in public schools. However, they conclude that the interaction effects are rather small and can be detected only in one out of ten indicators of social background.

Migrant parents with high educational ambitions may aim to send their children to a private school in order to overcome disadvantages [92]. Studies comparing the admission of migrant and native students to private institutions of higher education like colleges or universities [38, 93, 94] can show that migrants are overrepresented, especially in highly selective schools. In spite of their better chances of admission, migrant minorities earn lower college GPAs, thus again confirming the thesis of disadvantages [38]. 
TABLE 1: Variables on country level ( $n=57$, unweighted).

\begin{tabular}{lcccccc}
\hline Variable & Obs & Mean & SD & MIN & MAX & \% missing values \\
\hline Gini index (2005) & 56 & 35.2 & 8.1 & 24.7 & 58.6 & 1.8 \\
GNP per capita in 1.000 USD (2005) & 56 & 23,624 & 19,520 & 1,927 & 122,100 & 1.8 \\
\hline
\end{tabular}

Source: Our own calculations based on data from the UNDP [82].

We want to draw an analogy between the arguments regarding students from low socioeconomic background and those regarding children with migration backgrounds. In the first part of this section, we argue that migrant children suffer from several disadvantages. Therefore, the main research hypothesis of this paper is that children with migration backgrounds achieve better performance in private schools. We will distinguish between private government-dependent and private independent schools to see whether similar or different mechanisms are at work in these types of schools.

\section{Data}

The analyses of the paper are based on the data collected in the PISA 2006 survey. Data and technical information regarding the data records can be obtained from the OECD homepage. The PISA surveys (Program for International Student Assessment) are carried out by the OECD (Organization for Economic Cooperation and Development) as part of an indicator program and are supported by the member states and some additional participating states jointly [95]. The first data collection was carried out in 2000; the focus was to record especially the reading ability of students, in the second wave (2003) mathematics, and in the 2006 survey, knowledge in sciences were analyzed in more detail than the other two fields of ability.

The target group of the PISA surveys is the age-cohort of 15-year-old students [96, 97]. Sampling was carried out in two phases. In phase one a multistage cluster sample was drawn among schools (according to the type of school, federal states, and number of ninthgraders, respectively, 15year-olds attending the school). In phase two, a sample among students within schools was selected. In the 2006, survey, 57 countries with 14,365 schools and 398,750 students participated in PISA.

The empirical section of this paper analyzes mathematics and reading achievements as dependent variables. Mathematics competencies are regarded as a main field of competencies and serve besides language competencies as central criteria when teachers or parents make decisions concerning the educational trajectories of students. The goal of the assessment of competencies in the PISA-survey is to measure basic literacies that prove themselves in authentic situations [95]. On the other hand, it is not intended to register defined curricula, which in view of the wide variation between curricula in the participating countries would resemble the achievement of the impossible. The models for defining the individual achievement values are based on the item response theory, which is also called probabilistic test theory [98]. Since students did not have to answer all questions (multimatrix sampling), the one-dimensional Rasch model was used to calculate the achievement values.

In the following, the selection of independent variables will be explained by theoretical arguments. Then, the mean values of the independent variables will be reported (for variables and methods cf. OECD [99] and Adams and Wu [100]).

3.1. Independent and Dependent Variables. In Table 1, we summarize the mean values, standard deviation, and the minimum and maximum of the variables on country level. The first variable on country level is the GINI index describing the inequality of the income distribution within each country. Missing values in the country-level data for 2005 were replaced using the values of the most recent year published or additional information based on national reports published by the UNDP in cooperation with national agencies [101-107]. The second variable on country level is GNP per capita measuring the overall wealth of the country.

The proportions of children who attend private schools differ from country to country. In The Netherlands, more than $90 \%$ of all students at lower secondary level go to private schools, followed by the United Kingdom with 70\%. In most countries, $10 \%$ or less of all students attend private schools $[108,109]$; therefore, in a few countries, private schools are the regular type of school, but in most countries, they serve only small proportions of each cohort. To control for the selection processes and the external effects of private schools (like indirect effects on public school achievement by raising the quality of public education through competition or decreasing the quality by leaving a selective group of lowachieving students), we should take the proportion of private schooling in each country into consideration. Unfortunately, the distribution of this variable is largely skewed, so we decided not to include it.

Variables on school level are listed in Table 2. About 6\% of the schools in the 57 countries taking part in PISA 2006 are private independent schools, whereas $10 \%$ are private but government-dependent. However, both numbers differ considerably between countries. The average proportion of girls is $49 \%$. Most of the schools are located in villages (32\%), building the reference category. $22 \%$ of all schools reside either in small- or medium-sized towns, $15 \%$ in cities, and $9 \%$ in large cities with more than one million residents. The average proportion of migrants is $15 \%$ (due to our definition of foreign language spoken at home, see below), and on average, $24 \%$ of the parents are highly educated (at least one parent having education level ISCED 6 which resembles, e.g., a university degree).

As dependent variables on student level, we use the plausible values for the competencies in reading and 
TABLE 2: Variables on school level ( $n=14,365$, weighted by "final school weight").

\begin{tabular}{|c|c|c|c|c|c|c|}
\hline Variables & Obs & Mean & SD & MIN & MAX & $\%$ missing values \\
\hline Private school (independent) ${ }^{(\mathrm{a})}$ & 13,187 & 0.06 & 0.24 & 0 & 1 & 8.20 \\
\hline Private school (gov. dependent) ${ }^{(a)}$ & 13,187 & 0.10 & 0.29 & 0 & 1 & 8.20 \\
\hline Prop. girls & 13,604 & 0.49 & 0.13 & 0 & 1 & 5.30 \\
\hline \multicolumn{7}{|l|}{ Community size $\mathrm{b}^{(\mathrm{b})}$ : } \\
\hline $3,000-15,000$ & 13,747 & 0.22 & 0.41 & 0 & 1 & 4.30 \\
\hline $15,000-100,000$ & 13,747 & 0.22 & 0.41 & 0 & 1 & 4.30 \\
\hline $100,000-1,000,000$ & 13,747 & 0.15 & 0.36 & 0 & 1 & 4.30 \\
\hline$>1,000,000$ & 13,747 & 0.09 & 0.28 & 0 & 1 & 4.30 \\
\hline Prop. migrants ${ }^{(c)}$ & 14,345 & 0.15 & 0.29 & 0 & 1 & 0.14 \\
\hline Prop. parents with tertiary education ${ }^{(c, d)}$ & 14,351 & 0.24 & 0.23 & 0 & 1 & 0.10 \\
\hline School size (\# students) & 13,604 & 492.01 & 515.87 & 3 & 10,000 & 5.30 \\
\hline Prop. certified teachers & 10,189 & 0.84 & 0.30 & 0 & 1 & 29.07 \\
\hline Student-teacher ratio & 12,727 & 15.37 & 8.49 & 0 & 100 & 11.40 \\
\hline
\end{tabular}

${ }^{(a)}$ Ref.: public school.

(b) Ref.: $<3,000$

(c) Collapsed by student data.

(d) At least one of the parents has educational level ISCED 6.

TABle 3: Variables on student level ( $n=398,750$; weighted by “final student weight").

\begin{tabular}{|c|c|c|c|c|c|c|}
\hline Variables & Obs. & Mean & $\mathrm{SD}$ & MIN & MAX & $\%$ missing values \\
\hline DV: plausible value math 1 & 398,750 & 454.22 & 105.15 & 0.62 & 921.01 & 0.00 \\
\hline DV: plausible value reading 1 & 393,139 & 446.14 & 109.91 & 0.12 & 1083.51 & 1.41 \\
\hline Migrant $(1=\text { yes })^{(a)}$ & 384,488 & 0.14 & 0.34 & 0 & 1 & 3.58 \\
\hline Gender $(1=$ female $)$ & 398,746 & 0.50 & 0.50 & 0 & 1 & 0.00 \\
\hline HISEI $^{(\mathrm{b})}$ & 377,402 & 46.41 & 17.40 & 16.00 & 90.00 & 5.35 \\
\hline Age & 398,734 & 15.78 & 0.29 & 15.17 & 16.33 & 0.00 \\
\hline \multicolumn{7}{|l|}{ Number of books at home ${ }^{(\mathrm{c})}$ : } \\
\hline $11-25$ & 390,779 & 0.22 & 0.41 & 0 & 1 & 2.00 \\
\hline $26-100$ & 390,779 & 0.29 & 0.45 & 0 & 1 & 2.00 \\
\hline $101-200$ & 390,779 & 0.15 & 0.35 & 0 & 1 & 2.00 \\
\hline $201-500$ & 390,779 & 0.10 & 0.31 & 0 & 1 & 2.00 \\
\hline$>500$ & 390,779 & 0.06 & 0.23 & 0 & 1 & 2.00 \\
\hline
\end{tabular}

(a) Definition of "migrant": language spoken at home unequal to test language.

(b) Highest occupational status of parents.

(c) Ref.: $0-10$ books at home.

mathematics. The mean values of the plausible values used for the following analyses are 454 for mathematics and 446 for reading (see Table 3 ). Initially, the plausible values of the different test scores were calibrated at a mean of 500 and a standard deviation of 100 for all participating countries.

In the analyses of this paper, the language spoken at home serves as measure of ethnic origin. It can be assumed that children with inadequate comprehension of the language used at school cannot properly follow the lessons that are usually held in the test language, so that the acquisition of competencies suffers. We do not distinguish whether the language spoken at home is another official language used in the country. Another concept, nationality, is not used for classification, since former migrants might have changed their nationality so that they cannot be identified by this criterion. Additionally, mixed nationalities within one family may occur. The indicator country of birth of children and parents might not reflect disadvantages in school that result from language deficiency. On the other hand, we think it is a minor problem that classification by language is not appropriate for migrants from countries with the same language. According to language spoken at home, 14\% of students from the sample population are classified as migrants (see Table 3 ).

The two definitions for migrants (by language and by region or rather by country of birth of students, their parents and grandparents) are strongly confounded and in $87 \%$ of all cases identical. The size of the intersection of these two categorizations depends heavily on the country considered: in Chile-a large country with homogenous language use and very few regional migrants-the share of identical definitions is high with a maximum value of $99 \%$, whereas in Luxembourg - a tiny country with three official languages 
and a high share of regional migrants - the intersection of these two definitions reaches its minimum value of $28 \%$.

It has been pointed out that remarkable differences can be detected with respect to gender: female students' reading achievement is higher on average, but their mathematical and scientific literacy is worse than that of their male counterparts (cf. Stanat and Kunter [110]). This is why we will control for gender in the multivariate models. $50 \%$ of all students tested are female.

The results from several analyses of school achievement suggest controlling for social origin. The family environment heavily influences the early processes of socialization. The theoretical discussion distinguishes between primary and secondary effects of social origin [111]. Primary effects occur when children differ in their competencies because of their social origin, whereas secondary effects result from parental educational decisions (e.g., use of preschooling, selection of schools, or tracks) that depend on class-specific habits and attitudes. Analysis of the PISA data showed that the socioeconomic status of the family is of great importance for the differences in competency between the students. The largest social gradient of all countries was calculated for Germany [18, pp. 384-389]. The parents' socioeconomic status is determined with reference to their job title. Since this refers to the current job, the socioeconomic status of migrants is systematically underestimated in case they hold low-skilled jobs even though highly qualified. The given occupations of the parents were coded with the ISCO (international standard classification of occupations). With the help of this code, the job title can be converted into the "international socioeconomic index of occupational status" (ISEI according to Ganzeboom and Treiman [112]) or even into the customary prestige scores. PISA data include the socioeconomic status (ISEI) of mother, of father, or the highest status between the parents. In our analyses, we use the highest socioeconomic status between the parents (HISEI). The HISEI ranges from 16 to 90. The mean value of the HISEI in the sample used is 46 (Table 3). Although the population of students included in PISA consists of 15-yearolds we control for detailed age information, as the age range is, in fact, larger than one year, and age has been shown to be significant in previous studies [55].

Cultural capital [113] is acquired in an unconscious process during the primary and secondary socialization by contact with people who possess cultural capital [114]. During the acquisition of cultural capital, attitudes and cognition plus thought and action patterns used at home all play a decisive role. Parents pass on to their children habits corresponding with their social class. Schools are institutions of the middle class insofar as they require habits (e.g., interest in books, classical music, and arts) that are handed down especially in middle-class families. In its functional respect, this knowledge and the interest in the contents serve as a means of participation in the middleclass culture. Although what is meant by cultural capital may differ between societies and cultures, the importance as a phenomenon of general social relevance is not in question. In Bourdieu's [113], argumentation cultural capital is a mechanism of social reproduction of inequality. According
TABLE 4: Research hypotheses: effects on competencies in mathematics and reading.

\begin{tabular}{lc}
\hline Level I: individual & - \\
\hline Test language not spoken at home (migrant) & - \\
Gender (female) for mathematics & + \\
Gender (female) for reading & + \\
Highest socioeconomic status of parents (HISEI) & + \\
Cultural capital: number of books at home & + \\
Age & + \\
\hline Level II: school context & + \\
\hline Private school (independent) & + \\
Private school (gov. dependent) & $+/-$ \\
Proportion of girls at school & - \\
Community size & + \\
Proportion of migrants at school & + \\
Proportion of parents with tertiary education & + \\
School size & - \\
Proportion of certified teachers & + \\
Student-teacher ratio & + \\
\hline Level III: country & + \\
\hline Gross national income per capita (GNP) & \\
Income inequality: GINI index & + \\
\hline Cross-level effects & \\
\hline GINI* private schools (both types) & + \\
Gross national income per capita (GNP) ${ }^{*}$ private & + \\
\hline Private schools (both types)* migrant & + \\
\hline
\end{tabular}

to the cultural mobility model of DiMaggio [115] cultural capital can be used to compensate for disadvantages in social origin. Including indicators of socioeconomic status and of cultural capital within a regression model does help to distinguish the reproduction effect from the compensation effects. Empirical studies testing the assumptions of these hypotheses found that both mechanisms are effective (cf. a summary [116-120]). Cultural capital was found to further the achievements of students from lower social strata more than those of students from higher social strata [120].

The indicator for cultural capital in the family is the number of books at home with six categories building up five dummy variables. About 29\% of the students' families possess 26 to 200 books, which is the largest share (see Table 3). The advantage of this indicator is the low specification with respect to cultural contents so that it can be applied to different countries and cultural contexts. Unfortunately, the PISA consortium decided not to include indicators of educational resources at home and of cultural behavior that had been measured in the 2000 survey such as cultural communication in the family or attending cultural events.

3.2. Research Hypotheses. The research hypotheses are summarized in Table 4. Because of social deprivation, cultural distance between minority members and majority culture, 
selective migration or minority members have lower achievements. With respect to gender, the results differ. Girls show better reading abilities, but in mathematics or in science, they have poorer test results in most countries. Primary and secondary effects relating to social origin lead to positive effects on achievements. Similarly, higher cultural capital has a positive effect on both competencies examined. The older the students the higher their competencies should be.

As explained above, we expect that students in private schools (independent and government-dependent) have higher competencies than those attending public schools. The socioeconomic composition of private schools will be controlled in a multivariate model. The importance attributable to the composition will be derived from the effect of the proportion of parents with tertiary education in any given school. The proportion of girls in a school may correlate with a climate of high need for achievement or lower rates of deviant behavior. Therefore, we expect a positive effect of the proportion of girls in a school. The reverse argument is made for the proportion of migrants in school, leading to a negative effect. Another study shows that school size correlates positively to achievement [55]. Having schools with a high proportion of certified teachers and a low student-teacher ratio should create a beneficial learning environment for students. A last indicator describing the school context is community size. It is unclear whether size of town is positively or negatively correlated to educational achievement. A positive effect may be justified by a higher level of human capital among the population in large towns, higher importance of education for successful labor market participation, more homogeneous neighborhoods because of residential segregation, and greater attractiveness of the region. The size of the community has a negative effect on education if a higher proportion of migrants is living in larger cities and if life in metropolitan areas is related to an overabundance of stimuli detracting from learning and concentration.

As we argue that the effects of private schools depend on the societal context, we also consider the living standards in different countries measured by the gross national income. We expect that gross national income per capita (GNP) has a positive direct effect on competencies, since the national income reflects the human capital present in countries to a certain degree and the amount of money that can be invested in the education system. Another aspect is the degree of inequality. Existence of welfare state arrangements enlarges the proportion of GNP spent by the government and reduces the level of inequality [15]. Education is considered more and more as a means of active welfare state policy in order to enlarge competencies and chances of labor market participation.

Private schools have a larger impact on competencies in more polarized societies, since public schools suffer from having fewer resources. Therefore, we expect that the crosslevel interaction effect of private schools and inequality is positive. The wealthier a society is, the more money can be spent on public schooling; thus, private schooling is more advantageous in societies with low GNP-or, the higher the GNP, the lower the abilities measured in private schools. We expect that migrant children profit more from the beneficial context of private schools.

3.3. Methods. Generally, we use hierarchical linear models for our analyses with random effects for the variables of basic interest (dummy variables for private schools, migration status, and all the related cross-level terms), because they allow the variance between groups to be explained by group characteristics. Fixed effects are applied to all other variables aspiring to a sparse model strategy that is appropriate nevertheless (for more detail about fixed versus random coefficient models, see Snijders and Bosker [121]; for combining fixed and random effects, see Snijders [122]). The analyses were computed using HLM $6[123,124]$. Data management and imputation of missing data was conducted with STATA 11 (for multilevel analysis with STATA see [125]).

We decided not to apply conventional complete case analysis, which assumes "missing completely at random", since these presumptions were more restricted than alternative treatments of missing values (see overview at Schafer and Graham [126]; for more details, see Little and Rubin [127]). Multiple imputations assume only "missing at random". The disadvantage of multiple imputation versus simple imputation is, according to Rubin [128, page 17-18], the additional work required for creating, saving, and analyzing the data sets. This disadvantage is of minor importance as long as the number of imputations is restricted. To select the number of imputations $m$, the efficiency of an estimate based on $m$ imputations can be calculated relatively to an estimate based on infinite imputations by the formula $(1+\lambda / \mathbf{m})^{-1}$, with $\lambda$ as proportion of missing information $[126,128]$. Increasing the number of imputations from five to ten with a proportion of missing values of $5 \%$ increases the efficiency of the estimates only from $99.0 \%$ to $99.5 \%$; with a proportion of missing values of $10 \%$, the efficiency of the estimates increases from $98.0 \%$ to $99.0 \%$. The additional gain is thus negligible. Therefore, we restrict the number of imputations to five in our analyses. The higher the proportion of missing values in the data, the higher is the additional gain by enlarging the number of imputations $m$. We calculated the multiple imputations using the ado file "ice" (imputation by chained equations) in STATA that was written by Royston [129].

\section{Results}

As a first step, we investigate whether the school contexts of native-born and migrant students differ. The results from bivariate analyses (using multiple imputed data) are documented in Table 5.

The proportion of migrants attending private schoolsindependent and government dependent-is significantly higher than the proportion of native-born students; migrant students attend larger schools on average. Their studentteacher ratio is slightly more favorable, since it is significantly smaller. Having said this, migrants do suffer to a small extent from poorer conditions relating to school context (with respect to the proportion of girls in school) and to a greater degree in relation to the proportion of parents with tertiary education. The schools attended by migrants 
TABLE 5: School differences by migration status.

\begin{tabular}{|c|c|c|c|c|c|}
\hline \multicolumn{6}{|c|}{ Mean } \\
\hline & Migrants $(n=49,541)$ & Natives $(n=349,209)$ & test & value & $P$ value \\
\hline Private school (independent) ${ }^{(\mathrm{a})}$ & .09 & .05 & $\mathrm{Chi}^{2}$ & $1.2 * 10^{3}$ & $<.001$ \\
\hline Private school (gov. dependent) ${ }^{(a)}$ & .15 & .09 & $\mathrm{Chi}^{2}$ & $1.6 * 10^{3}$ & $<.001$ \\
\hline Prop. girls & .49 & .50 & t-test & 8.27 & $<.001$ \\
\hline \multicolumn{6}{|l|}{ Community size: } \\
\hline$<3,000$ & .11 & .10 & $\mathrm{Chi}^{2}$ & 10.55 & $<.001$ \\
\hline $3,000-15,000$ & .26 & .22 & $\mathrm{Chi}^{2}$ & 408.58 & $<.001$ \\
\hline $15,000-100,000$ & .30 & .31 & $\mathrm{Chi}^{2}$ & 14.61 & $<.001$ \\
\hline $100,000-1,000,000$ & .26 & .25 & $\mathrm{Chi}^{2}$ & 10.62 & $<.001$ \\
\hline$>1,000,000$ & .07 & .11 & $\mathrm{Chi}^{2}$ & 833.33 & $<.001$ \\
\hline Prop. migrants ${ }^{(b)}$ & .56 & .06 & t-test & $-3.1 * 10^{2}$ & $<.001$ \\
\hline Prop. parents with tertiary education & .23 & .30 & t-test & 70.74 & $<.001$ \\
\hline School size (\# students) & 971 & 815 & t-test & -38.02 & $<.001$ \\
\hline Prop. certified teachers & .83 & .84 & t-test & 9.25 & $<.001$ \\
\hline Student-teacher ratio & .15 & .16 & t-test & 18.86 & $<.001$ \\
\hline
\end{tabular}

${ }^{(a)}$ Ref.: public school.

(b) Collapsed by student data.

(c) At least one of the parents has educational level ISCED 6.

are more often situated in villages or small towns, whereas native students more often attend schools in large cities (although the migrant population more often resides in larger cities [130]). With the data at hand, it cannot be determined whether this pattern is due to different places of residence or to mobility and school choice. The teachers of native students are slightly more highly qualified on average. The largest difference between migrants and native students is the proportion of migrants attending the same school. Migrants on average visit a school with a share of $56 \%$ migrants, whereas native students go to schools with an average proportion of $6 \%$ migrants.

Do migrants have lower abilities than those of nativeborn students? Are private schools beneficial for their students? And do migrants do better in private schools? These three questions are examined in model 1 without any control variables. Do characteristics on country level (model 2), school level (model 3), or individual level (model 4) explain the three main effects examined in model 1 at least to some extent (for each model, see Table 6 for mathematics and Table 7 for reading competencies)?

In model 1 (Tables 6 and 7), only migration status, the two private school dummy variables, and the cross-level interaction between them are included. All main hypotheses are tentatively confirmed for mathematics (see Table 6), showing a better performance for native students, students in private schools, and with migrants benefitting significantly more from attending private schools. While both types of private schools are significant for mathematics, private independent schools have a larger positive effect on mathematics competencies and are more beneficial to migrants than private government-dependent schools. The latter is almost significant at 5\% level for reading competencies. Additionally, concerning reading ability, migrants do not benefit significantly more by attending private independent schools.
Country-level variables and further cross-level effects were included in model 2 reducing the error variance on level 3 by $33 \%$ for mathematics and 30\% for reading competencies. Both private school dummy variables become insignificant if controlling for country-level variables. In addition, small income inequalities within of a country (measured by the GINI-Index) as well as the wealth of a country (measured by GNP per capita) both have a significantly positive influence on the mathematics achievements in the PISA tests, whereas for reading competencies, the income inequality is slightly below the 5\%-significance-level.

In model 3, school-level variables are also included explaining 34\% (mathematics competencies) and 33\% (reading competencies) of the error variance on level 2. If controlling for school context for both competencies examined the migration effect concerning size and significance remains robust. A higher proportion of girls in a school (unfortunately, we do not have any class information) leads to better competencies, especially in reading and also in mathematics. Whereas a high share of migrants has a negative effect on both competencies, it is the high proportion of parents with tertiary education that has a very strong positive effect. A high share of certified teachers is only beneficial for the enhancement of reading abilities but not so for mathematics. Variations of the student-teacher ratio is not associated with any improvement of competencies; however, schools located in larger communities provide a better environment for developing reading skills.

In model 4, further individual-level variables such as gender, socioeconomic background, cultural capital, and age are included, explaining additionally $7 \%$ (mathematics competencies) and 8\% (reading competencies) of the level 1 error variance. The migration effect is reduced considerably but remains significantly negative; this means that part of the effect is due to the lower socioeconomic status and 
TABLE 6: Hierarchical multilevel models: determinants of mathematics competencies.

\begin{tabular}{|c|c|c|c|c|}
\hline Model & $\begin{array}{c}(1) \\
\text { Coeff. (T-ratio) } \\
\end{array}$ & $\begin{array}{c}(2) \\
\text { Coeff. }(T \text {-ratio }) \\
\end{array}$ & $\begin{array}{c}(3) \\
\text { Coeff. (T-ratio) } \\
\end{array}$ & $\begin{array}{c}(4) \\
\text { Coeff. (T-ratio) } \\
\end{array}$ \\
\hline \multicolumn{5}{|l|}{ Fixed effects } \\
\hline Intercept & $464.67(56.83)^{* * *}$ & $501.22(14.84)^{* * *}$ & $441.95(12.22)^{* * *}$ & $261.14(7.48)^{* * *}$ \\
\hline \multicolumn{5}{|l|}{ Student level (level 1) } \\
\hline Migrant & $-19.32(-7.46)^{* * *}$ & $-19.37(-7.46)^{* * *}$ & $-18.57(-7.06)^{* * *}$ & $-13.49(-5.96)^{* * *}$ \\
\hline Female & & & & $-16.99(-70.32)^{* * *}$ \\
\hline HISEI & & & & $0.54(61.90)^{* * *}$ \\
\hline Age & & & & $8.92(21.65)^{* * *}$ \\
\hline \multicolumn{5}{|l|}{ \# books at home ${ }^{(\mathrm{a})}$ : } \\
\hline $11-25$ & & & & $8.12(17.56)^{* * *}$ \\
\hline $26-100$ & & & & $24.18(63.83)^{* * *}$ \\
\hline $101-200$ & & & & $35.08(75.79)^{* * *}$ \\
\hline $201-500$ & & & & $49.95(98.96)^{* * *}$ \\
\hline$>500$ & & & & $48.96(77.83)^{* * *}$ \\
\hline \multicolumn{5}{|l|}{$\begin{array}{l}\text { School level (level 2) } \\
\text { School type }\end{array}$} \\
\hline Private school (indep.) & $39.91(6.90)^{* * *}$ & $18.22(0.59)$ & $11.91(0.49)$ & $9.73(0.42)$ \\
\hline Private school (gov. depend.) & $11.81(1.99)^{*}$ & $4.90(0.14)$ & $-30.86(-1.25)$ & $-28.42(-1.20)$ \\
\hline Prop. girls & & & $11.65(5.05)^{* * *}$ & $23.17(10.71)^{* * *}$ \\
\hline Prop. migrants & & & $-25.72(-9.87)^{* * *}$ & $-23.05(-9.44)^{* * *}$ \\
\hline Prop. parents with tertiary edu. & & & $157.67(63.42)^{* * *}$ & $118.60(50.12)^{* * *}$ \\
\hline Prop. certified teachers & & & $2.29(1.47)$ & $2.18(1.50)$ \\
\hline School size & & & $0.01(15.56)^{* * *}$ & $0.01(15.23)^{* * *}$ \\
\hline Student-teacher ratio & & & $-0.08(-1.28)$ & $-0.08(-1.31)$ \\
\hline \multicolumn{5}{|l|}{ Community size ${ }^{(c)}$ : } \\
\hline $3,000-15,000$ & & & $3.02(2.02)^{*}$ & $1.92(1.38)$ \\
\hline $15,000-100,000$ & & & $3.24(2.18)^{*}$ & $1.47(1.06)$ \\
\hline $100,000-1,000,0000$ & & & $0.43(0.27)$ & $-1.76(-1.19)$ \\
\hline$>1,000,000$ & & & $2.69(1.39)$ & $0.11(0.06)$ \\
\hline \multicolumn{5}{|l|}{ Country level (level 3) } \\
\hline Gini-Index (2005) & & $-1.72(-2.06)^{*}$ & $-1.74(-1.95)$ & $-1.49(-1.77)$ \\
\hline GNP per capita (2005) & & $0.00(2.83)^{* *}$ & $0.00(2.99)^{* *}$ & $0.00(2.96)^{* *}$ \\
\hline \multicolumn{5}{|l|}{ Cross-level effects } \\
\hline Gini* priv. school (indep.) & & $0.98(1.40)$ & $0.09(0.17)$ & $0.06(0.11)$ \\
\hline Gini* priv. school (gov. dep.) & & $0.57(0.73)$ & $0.98(1.76)$ & $0.84(1.57)$ \\
\hline GNP* priv. school (indep.) & & $-0.00(-1.52)$ & $-0.00(-2.18)^{*}$ & $-0.00(-2.21)^{*}$ \\
\hline GNP* priv. school (gov. dep.) & $11.34(3.22)^{* *}$ & $-0.00(-1.17)$ & $-0.00(-0.44)$ & $-0.00(-0.26)$ \\
\hline Priv. school (indep.)* migrant & $8.79(2.52)^{*}$ & $11.20(3.18)^{* *}$ & $10.23(2.54)^{*}$ & $8.55(2.26)^{*}$ \\
\hline Priv. school (gov. dep.)* migrant & & $7.42(2.29)^{*}$ & $6.77(2.01)^{*}$ & $4.44(1.40)$ \\
\hline \multicolumn{5}{|l|}{ Random effects } \\
\hline$\delta($ error variance level 1$)$ & 4915 & 4916 & 4918 & 4557 \\
\hline$\varepsilon($ error variance level 2$)$ & 3008 & 3009 & 2000 & 1719 \\
\hline$\gamma($ error variance level 3$)$ & 3767 & 2527 & 2642 & 2288 \\
\hline Deviance (\# estimated parameters) & $4,562,423(31)$ & $4,562,406(37)$ & $4,557,370(47)$ & $4,526,061(55)$ \\
\hline $\mathrm{N}_{\mathrm{L} 1}$ & 398,750 & 398,750 & 398,750 & 398,750 \\
\hline $\mathrm{N}_{\mathrm{L} 2}$ & 14,365 & 14,365 & 14,365 & 14,365 \\
\hline $\mathrm{N}_{\mathrm{L} 3}$ & 57 & 57 & 57 & 57 \\
\hline
\end{tabular}

(a) Ref.: $<11$.

(b) Ref.: public school.

(c) Ref.: $<3,000$. 
TABLE 7: Hierarchical multilevel models: determinants of reading competencies.

\begin{tabular}{|c|c|c|c|c|}
\hline Model & $\begin{array}{c}(1) \\
\text { Coeff. (T-ratio) }\end{array}$ & $\begin{array}{c}\text { (2) } \\
\text { Coeff. (T-ratio) }\end{array}$ & $\begin{array}{c}(3) \\
\text { Coeff. (T-ratio) }\end{array}$ & $\begin{array}{c}(4) \\
\text { Coeff. (T-ratio) }\end{array}$ \\
\hline \multicolumn{5}{|l|}{ Fixed effects } \\
\hline Intercept & $455.43(58.64)^{* * *}$ & $476.87(13.87)^{* * *}$ & $380.27(10.49)^{* * *}$ & $196.22(5.62)^{* * *}$ \\
\hline \multicolumn{5}{|l|}{ Student level (level 1) } \\
\hline Migrant & $-27.78(-9.67)^{* * *}$ & $-27.76(-9.63)^{* * *}$ & $-26.77(-9.13)^{* * *}$ & $-20.48(-7.57)^{* * *}$ \\
\hline Female & & & & $29.26(86.69)^{* * *}$ \\
\hline HISEI & & & & $0.57(66.66)^{* * *}$ \\
\hline Age & & & & $8.68(18.30)^{* * *}$ \\
\hline \multicolumn{5}{|l|}{ \# books at home ${ }^{(\mathrm{a})}$ : } \\
\hline $11-25$ & & & & $11.23(21.90)^{* * *}$ \\
\hline $26-100$ & & & & $25.83(53.67)^{* * *}$ \\
\hline $101-200$ & & & & $37.33(67.90)^{* * *}$ \\
\hline $201-500$ & & & & $49.61(77.46)^{* * *}$ \\
\hline$>500$ & & & & $46.67(66.86)^{* * *}$ \\
\hline \multicolumn{5}{|l|}{ School level (level 2) } \\
\hline \multicolumn{5}{|l|}{ School type $e^{(\mathrm{b})}$} \\
\hline Private school (indep.) & $43.89(7.55)^{* * *}$ & $20.86(0.68)$ & $21.21(0.91)$ & $22.55(1.03)$ \\
\hline Private school (gov. depend.) & $12.00(1.91)$ & $-2.69(-0.08)$ & $-35.49(-1.43)$ & $-33.31(-1.48)$ \\
\hline Prop. girls & & & $68.92(26.74)^{* * *}$ & $37.33(15.63)^{* * *}$ \\
\hline Prop. migrants & & & $-32.02(-10.82)^{* * *}$ & $-29.12(-10.54)^{* * *}$ \\
\hline Prop. parents with tertiary edu. & & & $151.68(57.07)^{* * *}$ & $112.76(45.35)^{* * *}$ \\
\hline Prop. certified teachers & & & $3.65(2.15)^{*}$ & $3.90(2.48)^{*}$ \\
\hline School size & & & $0.01(15.39)^{* * *}$ & $0.01(14.84)^{* * *}$ \\
\hline Student-teacher ratio & & & $-0.02(-0.29)$ & $-0.03(-0.40)$ \\
\hline \multicolumn{5}{|l|}{ Community size ${ }^{(\mathrm{c})}$ : } \\
\hline $3,000-15,000$ & & & $4.93(2.99)^{* *}$ & $3.45(2.25)^{*}$ \\
\hline $15,000-100,000$ & & & $8.14(4.91)^{* * *}$ & $5.79(3.75)^{* * *}$ \\
\hline $100,000-1,000,0000$ & & & $6.07(3.47)^{* * *}$ & $3.47(2.13)^{*}$ \\
\hline$>1,000,000$ & & & $9.72(4.49)^{* * *}$ & $6.84(3.39)^{* * *}$ \\
\hline \multicolumn{5}{|l|}{ Country level (level 3) } \\
\hline Gini-Index (2005) & & $-1.42(-1.68)$ & $-1.31(-1.47)$ & $-0.96(-1.14)$ \\
\hline GNP per capita (2005) & & $0.00(3.29)^{* * *}$ & $0.00(3.48)^{* * *}$ & $0.00(3.34)^{* * *}$ \\
\hline \multicolumn{5}{|l|}{ Cross-level effects } \\
\hline Gini* priv. school (indep.) & & $1.06(1.53)$ & $0.11(0.21)$ & $-0.05(-0.09)$ \\
\hline Gini* priv. school (gov. dep.) & & $0.65(0.81)$ & $1.09(1.94)$ & $0.97(1.90)$ \\
\hline GNP* priv. school (indep.) & $5.98(1.44)$ & $-0.00(-1.79)$ & $-0.00(-3.04)^{* *}$ & $-0.00(-3.10)^{* *}$ \\
\hline GNP* priv. school (gov. dep.) & $9.62(2.45)^{*}$ & $-0.00(-0.66)$ & $-0.00(-0.16)$ & $0.00(0.08)$ \\
\hline Priv. school (indep.)* migrant & & $5.99(1.42)$ & $5.82(1.34)$ & $3.69(0.92)$ \\
\hline Priv. school (gov. dep.)* migrant & & $9.49(2.55)^{*}$ & $9.38(2.55)^{*}$ & $6.67(1.95)$ \\
\hline \multicolumn{5}{|l|}{ Random effects } \\
\hline$\delta$ (error variance level 1$)$ & 5679 & 5678 & 5681 & 5211 \\
\hline$\varepsilon$ (error variance level 2) & 3645 & 3645 & 2426 & 2056 \\
\hline$\gamma($ error variance level 3$)$ & 3389 & 2386 & 2563 & 2248 \\
\hline Deviance (\# estimated parameters) & $4,621,099(31)$ & $4,621,080(37)$ & $4,616,051(47)$ & $4,580,643(55)$ \\
\hline $\mathrm{N}_{\mathrm{L} 1}$ & 398,750 & 398,750 & 398,750 & 398,750 \\
\hline $\mathrm{N}_{\mathrm{L} 2}$ & 14,365 & 14,365 & 14,365 & 14,365 \\
\hline $\mathrm{N}_{\mathrm{L3}}$ & 57 & 57 & 57 & 57 \\
\hline
\end{tabular}

(a) Ref.: $<11$

(b) Ref.: public school.

(c) Ref.: $<3,000$. 
Without control variables (model 1)

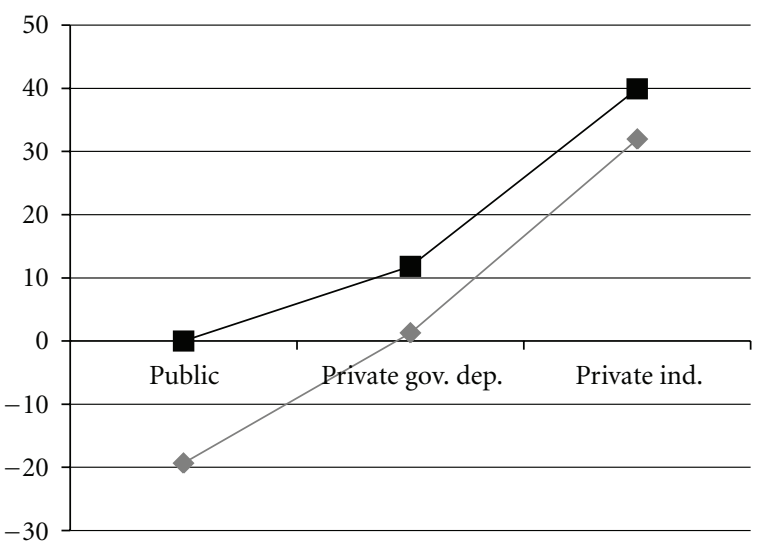

$\checkmark$ Migrants

- Natives

(a)

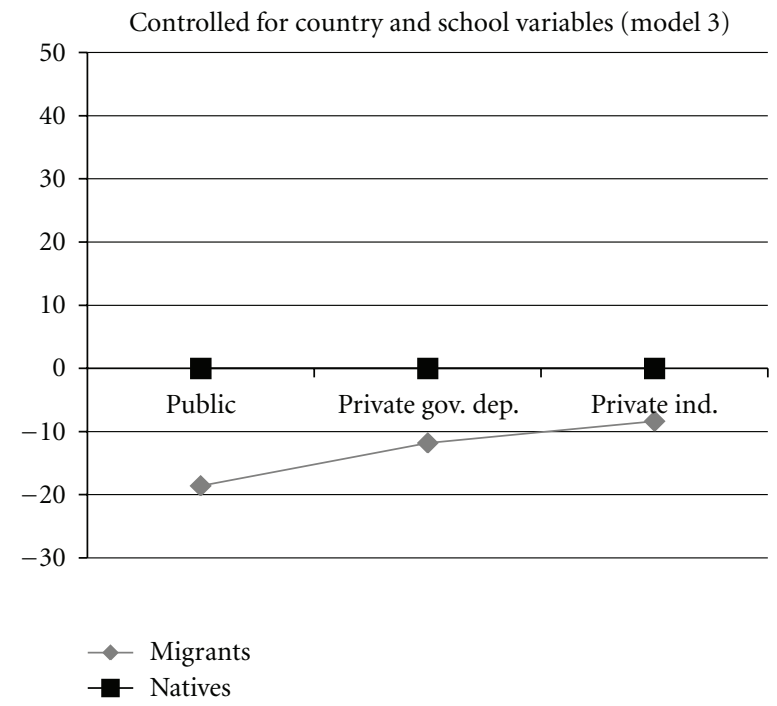

(c)

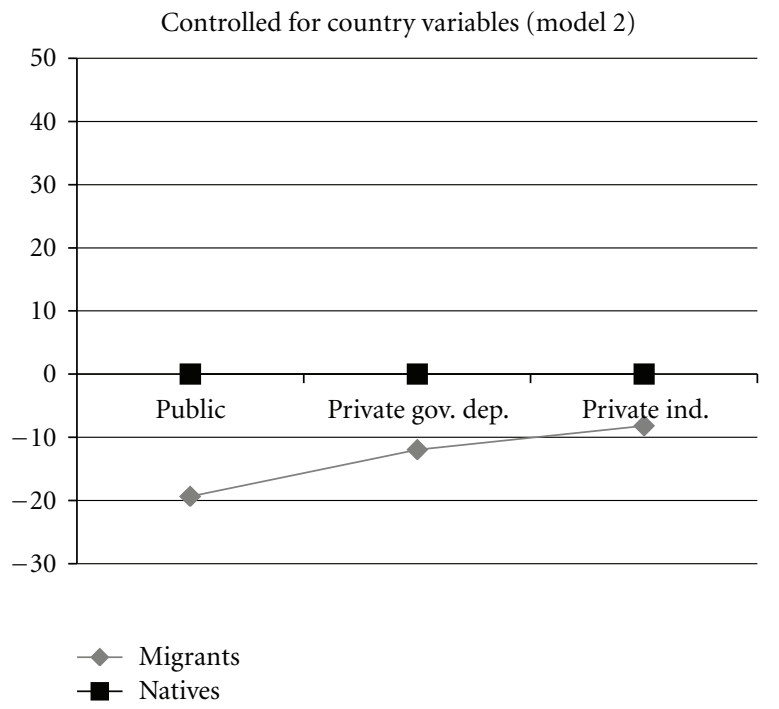

(b)

Controlled for country, school and student variables (model 4)

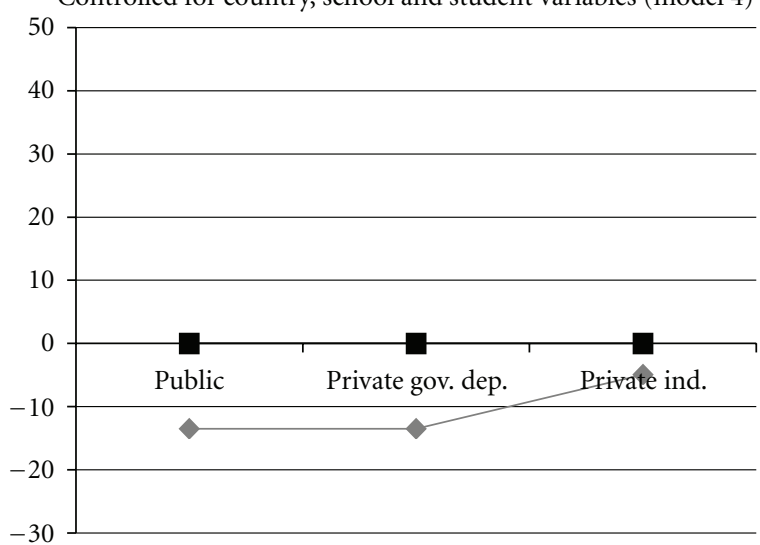

(d)

FIGURE 1: Effects of migration status and school type on mathematics competencies.

cultural capital of migrants. The cross-level effect private government-dependent school type on the migration effect becomes insignificant if controlling for variables on the individual level; girls reach significantly lower scores in mathematics but outperform boys in reading skills. Higher socioeconomic background and higher cultural capital increase both competencies.

What happens to the competencies of migrant students in different types of schools after country-, school-, and individual-level variables are controlled for? Figures 1 and 2 display the central results concerning the differences between reading and mathematics competencies calculated from significant main and interaction effects in the models 1 to 4 in Tables 6 and 7. A first glance at the figures shows that for native students, variations in achievement between different types of school disappear as soon as country-level variables are included. For migrant students, the situation is more complex; in mathematics, most of the effects of both types of private schools are explained by country-level variables. In the fourth model, where we control for country-, school-, and individual-level covariates, migrant students in private independent schools still achieve better results than migrant students in public or in private government-dependent schools. Additional models (not displayed in Table 6; available upon request from the authors) show that accounting for either the socioeconomic status of parents (HISEI) or cultural capital of the family (number of books at home) renders the positive interaction effect of private governmentdependent schools insignificant. With regards to reading, differences between school types vanish in the fourth model. Before individual-level variables are controlled, the reading competencies of migrant students attending private 


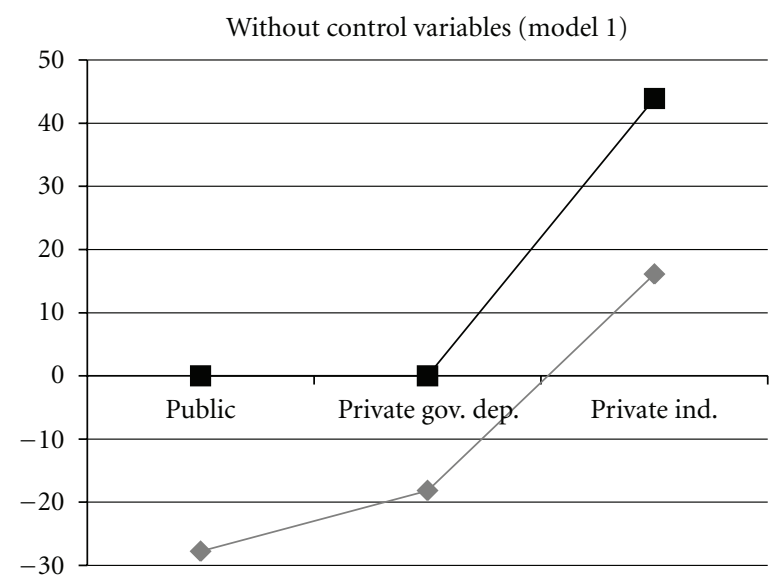

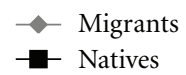

(a)
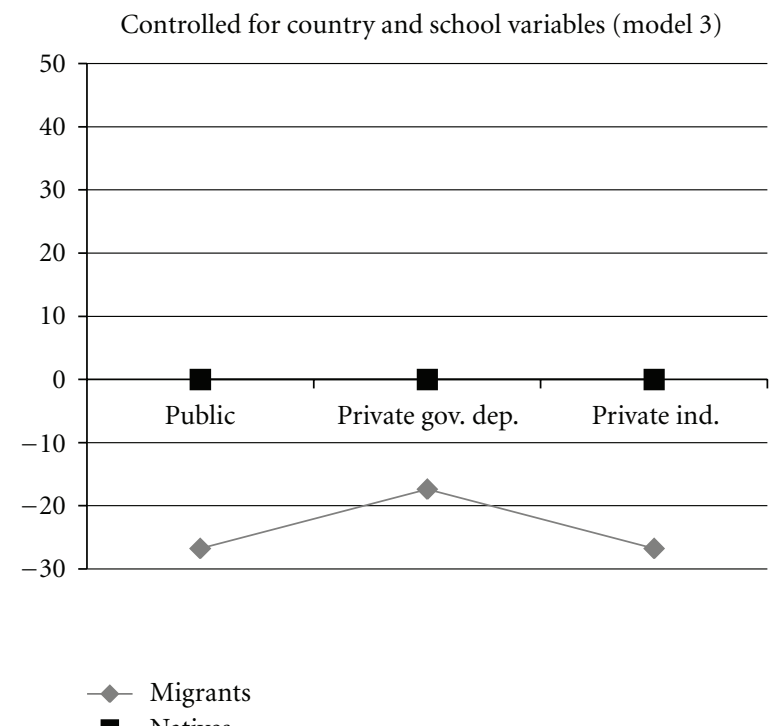

Natives

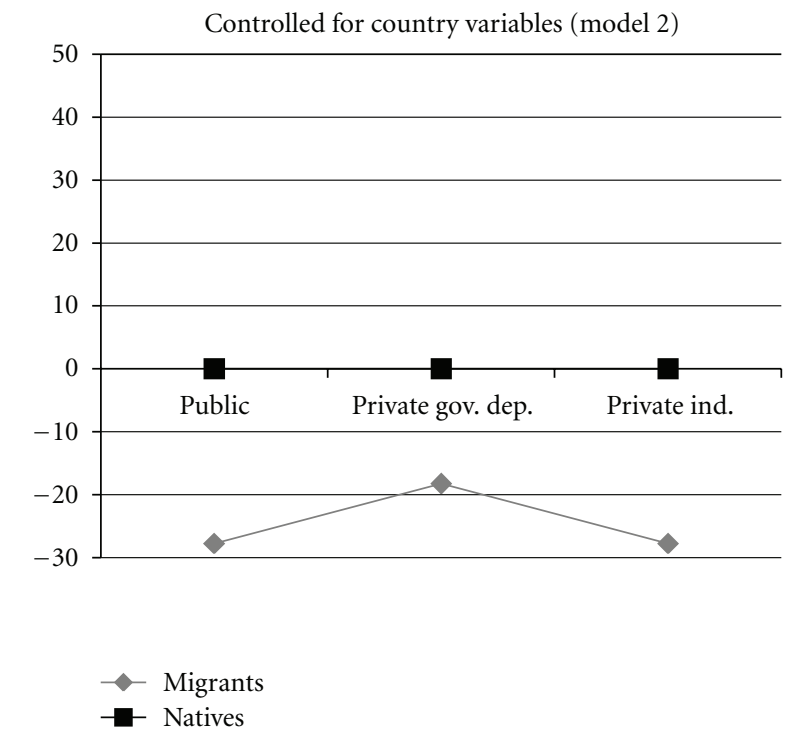

(b)

Controlled for country, school and student variables (model 4)

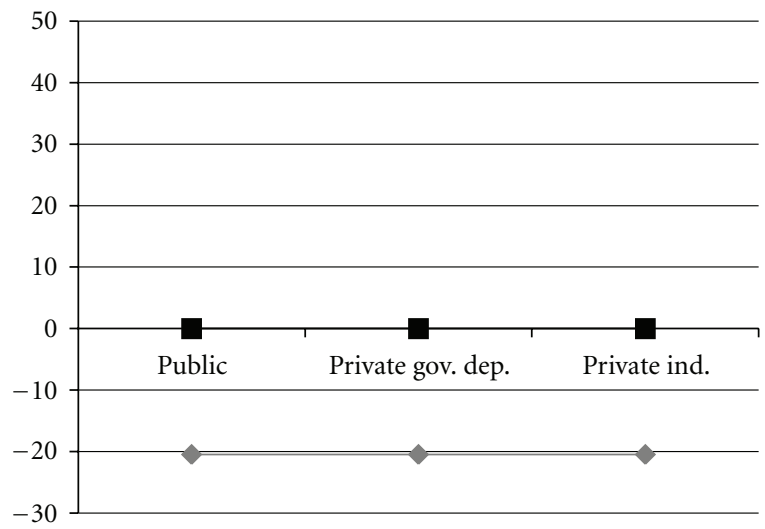

Migrants

Natives

(c)

(d)

FIGURE 2: Effects of migration status and school type on reading competencies.

government-dependent schools are better than in both other types of schools. We again tried to discover which of the individual-level variables is responsible for the dissolving positive effect of private government-dependent schools on the achievement of migrant students. It is not a single variable but rather the combination of three variables that is responsible for this result: socioeconomic status (HISEI), number of books, and gender (not displayed in Table 7).

\section{Discussion}

The result of our investigations is that mathematics and reading achievements of migrant children are poorer than those of native-born children confirming the results from existing evidence. After the socioeconomic background and school-level variables are controlled for, the disadvantage of migrant children is reduced to some extent. At first, students in private independent and government-dependent schools tend to have better results than students in public schools, but after controlling for country-level characteristics, the advantages disappear. Thus, we do not confirm the finding from Dronkers and Robert [70] that students in private independent schools perform even worse than those in public schools. However, as we do not completely replicate their models, strictly speaking, the results cannot be compared: Dronkers and Robert [70] do not include the country-level variables that were the main reason for vanishing school type effects in our models, and we do not control for teaching 
and learning conditions in the school and school climate as Dronkers and Robert [70] do. Do private schools offer learning environments especially beneficial to migrant students? The answer to this question is ambiguous: in mathematics, independent schools yield an advantage to migrant students, whereas government-dependent schools do not. Reading skills of migrant students do not differ between the types of schools once individual-level covariates are controlled for.

Several other hypotheses have been confirmed in line with existing literature: achievements correlate positively with families' socioeconomic status, cultural capital, age of student, proportion of girls in school, proportion of highly educated parents in school, and size of school and negatively with the share of migrant students in school; thus confirming the thesis that in addition to individual characteristics, school context matters. We found evidence of an effect of teacher qualifications in reading, but not in mathematics, and no effect of the student-teacher-ratio on competencies. The results concerning community size do not provide a simple explanation, and therefore, further research is required to determine whether regional context in terms of prosperity, different patterns of housing segregation, or other factors that influence skills and literacy correlate to size of community.

We presented interesting and novel results concerning country characteristics: wealth measured by GNP per capita indicates a high level of human capital in a country, and thus is clearly correlated to achievement. Inequality in a country was expected to be negatively correlated to competencies, and in mathematics, a first approach confirmed this thesis; however, it turned out that school-level and individual-level characteristics overruled this effect. Our investigations went beyond recent studies by including the country-level contexts and cross-level effects to investigate whether private schools have different functions depending on the conditions in the respective countries.

Future research should elaborate theoretically and empirically on further country-level indicators that might influence the functioning of education. Promising aspects are those that describe the social mechanisms that can explain those processes of social mobility that either mitigate or foster inequality. Additionally, the research on features of the education systems should be included as well as research on policies of equal opportunity and equal treatment. Educational achievement is of high importance for labor market integration, social and political participation, and other life chances such as health and well-being and therefore it is important to discover the mechanisms that impede migrants' achievements.

\section{Acknowledgments}

An earlier version of this paper was presented at the First ISA Forum 2008 in Barcelona and at the conference Analytrics2nd Paris International Conference on Education, Economy, and Society 2010. The authors thank Jaap Dronkers, Sylke V. Schnepf, Peter Robert, Oscar Valiente, and further participants of these conferences as well as two anonymous reviewers for very helpful comments.

\section{References}

[1] H. Diefenbach, "Bildungschancen und Bildungs(miss)erfolg von ausländischen Schülern oder Schülern aus Migrantenfamilien im System schulischer Bildung," in Bildung als Privileg? Erklärungen und Befunde zu den Ursachen der Bildungsungleichheit, R. Becker and W. Lauterbach, Eds., pp. 225-249, VS Verlag, Wiesbaden, Germany, 2004.

[2] C. Kristen, "Hauptschule, Realschule or Gymnasium? Ethnische Unterschiede am ersten Bildungsübergang," Kölner Zeitschrift für Soziologie und Sozialpsychologie, vol. 54, no. 3, pp. 534-623, 2002.

[3] C. Kristen, "Ethnische Unterschiede im deutschen Schulsystem," Aus Politik und Zeitgeschichte, vol. 21-22, pp. 26-32, 2003.

[4] A. Reinberg and M. Hummel, Vertrauter Befund. Höhere Bildung schützt auch in der Krise vor Arbeitslosigkeit. IAB Kurzbericht 9/2005, http://www.iab.de/.

[5] C. Lauer, Education and labour market outcomes. A FrenchGerman comparison, ZEW economic studies, 30, Physica, Heidelberg, Germany, 2005.

[6] H. Diefenbach, Kinder und Jugendliche aus Migrantenfamilien im deutschen Bildungssystem. Erklärungen und empirische Befunde, VS Verlag, Wiesbaden, Germany, 2007.

[7] R. G. Rumbaut, "Ages, life stages, and generational cohorts: decomposing the immigrant first and second generations in the United States," International Migration Review, vol. 38, no. 3, pp. 1160-1205, 2004.

[8] C. Gross, A. Jobst, M. Jungbauer-Gans, and J. Schwarze, "Educational returns in the life course," forthcoming in Zeitschrift für Erziehungswissenschaft.

[9] J. S. Coleman, E. Q. Campbell, C. J. Hobson et al., Equality of Educational Opportunity, United States Government Printing Office, Washington, DC, USA, 1996.

[10] J. S. Coleman, T. Hoffer, and S. Kilgore, High School Achievement. Public, Catholic, and Private Schools Compared, Basic Books, New York, NY, USA, 1982.

[11] A. M. Greeley, Catholic high schools and minority students, Transactions, New Brunswik, NJ, USA, 1982.

[12] T. Hoffer, A. M. Greeley, and J. S. Coleman, "Achievement growth in public and catholic schools," Sociology of Education, vol. 58, pp. 74-97, 1985.

[13] J. S. Coleman, "Social capital in the creation of human capital," American Journal of Sociology, vol. 94, pp. S95-S121, 1988.

[14] T. C. Dawson and E. A. Helland, "Helping hand. How private philantrophy and catholic schools serve low-income children in Los Angeles," Pacific Research Institute for Public Policy, San Francisco, USA, 2001http://www.pacificresearch.org/ docLib/200702082_helpinghand.pdf.

[15] C. G. Ullrich, Soziologie des Wohlfahrtsstaates. Eine Einführung, Campus, Frankfurt, Germany, 2005.

[16] C. Kristen and N. Granato, "The educational attainement of the second generation in Germany. Social origins and ethnic inequality," Tech. Rep., Institut für Arbeitsmarkt- und Berufsforschung (IAB), Nürnberg, Germany, 2007.

[17] F. Büchel and G. G. Wagner, "Soziale Differenzen der Bildungschancen in West deutschland-unter besonderer Berücksichtigung von Zuwandererkindern," in Lebenslagen im Wandel. Sozialberichterstattung im Längsschnitt, Sozioökonomische Daten und Analysen für die Bundesrepublik Deutschland 7, W. Zapf, J. Schupp, and R. Habich, Eds., pp. 80-96, Campus, Frankfurt, Germany, 1996. 
[18] J. Baumert and G. Schümer, "Familiäre Lebensverhältnisse, Bildungsbeteiligung und Kompetenzerwerb," in Deutsches PISA-Konsortium: PISA 2000. Basiskompetenzen von Schülerinnen und Schülern im internationalen Vergleich, pp. 323-407, Leske + Budrich, Opladen, Germany, 2001.

[19] P. Stanat, "Schulleistungen von Jugendlichen mit Migrationshintergrund. Differenzierung deskriptiver Befunde aus PISA und PISA-E," in PISA 2000. Ein differenzierter Blick auf die Länder der Bundesrepublik Deutschland, J. Baumert, C. Artelt, E. Klieme et al., Eds., pp. 243-260, Leske + Budrich, Opladen, Germany, 2003.

[20] G. Ramm, M. Prenzel, H. Heidemeier, and O. Walter, "Soziokulturelle Herkunft: Migration," in PISA 2003. Der Bildungsstand der Jugendlichen in Deutschland-Ergebnisse des zweiten internationalen Vergleichs, M. Prenzel, J. Baumert, W. Blum et al., Eds., pp. 254-272, Waxmann, Münster, Germany, 2004.

[21] G. Ramm, O. Walter, H. Heidemeier, and M. Prenzel, "Soziokulturelle Herkunft und Migration im Ländervergleich,” in PISA 2003. Der zweite Vergleich der Länder in DeutschlandWas wissen und können Jugendliche? M. Prenzel, J. Baumert, W. Blum et al., Eds., pp. 269-298, Waxmann, Münster, Germany, 2005.

[22] O. Walter and P. Taskinen, "Kompetenzen und bildungsrelevante Einstellungen von Jugendlichen mit Migrationshintergrund in Deutschland: ein Vergleich mit augewählten OECD-Staaten," in PISA 2006. Die Ergebnisse der dritten internationalen Vergleichsstudie, M. Prenzel, C. Artelt, J. Baumert et al., Eds., pp. 337-366, Waxmann, Münster, Germany, 2007.

[23] R. D. Alba, J. Handl, and W. Müller, "Ethnische Ungleichheiten im deutschen Bildungssystem," Kölner Zeitschrift für Soziologie und Sozialpsychologie, vol. 46, pp. 209-237, 1994.

[24] O. Walter, "Die Entwicklung der mathematischen und der naturwissenschaftlichen Kompetenzen von Jugendlichen mit Migrationshintergrund im Verlauf eines Schuljahres," in PISA 2003. Untersuchungen zur Kompetenzentwicklung im Verlauf eines Schuljahres, M. Prenzel, C. Artelt, J. Baumert et al., Eds., pp. 249-275, Waxmann, Münster, Germany, 2006.

[25] H. Esser, "Familienmigration und Schulkarriere ausländischer Kinder und Jugendlicher," in Generation und Identität. Theoretische und empirische Beiträge zur Migrationssoziologie. Studien zur Sozialwissenschaft 97, H. Esser and J. Friedrichs, Eds., pp. 127-146, Westdeutscher, Opladen, Germany, 1990.

[26] J. Dronkers and M. Levels, "Do school segregation and school resources explain region-of-origin differences in the mathematics achievement of immigrant students?" Educational Research and Evaluation, vol. 13, no. 5, pp. 435-462, 2007.

[27] M. Levels and J. Dronkers, "Educational performance of native and immigrant children from various countries of origin," Ethnic and Racial Studies, vol. 31, no. 8, pp. 1404-1425, 2008.

[28] Y. Brinbaum and H. Cebolla-Boado, "The school careers of ethnic minority youth in France: success or disillusion?" Ethnicities, vol. 7, no. 3, pp. 445-474, 2007.

[29] H. G. van de Werfhorst and F. van Tubergen, "Ethnicity, schooling, and merit in the Netherlands," Ethnicities, vol. 7, no. 3, pp. 416-444, 2007.

[30] K. Phalet, P. Deboosere, and V. Bastiaenssen, "Old and new inequalities in educational attainment: ethnic minorities in the Belgian census 1991-2001," Ethnicities, vol. 7, no. 3, pp. 390-415, 2007.
[31] S. N. Fekjær, "New differences, old explanations: can educational differences between ethnic groups in Norway be explained by social background?" Ethnicities, vol. 7, no. 3, pp. 367-389, 2007.

[32] A. Lutz, "Barriers to high-school completion among immigrant and later-generation Latinos in the USA: language, ethnicity and socioeconomic status," Ethnicities, vol. 7, no. 3, pp. 323-342, 2007.

[33] C. Rothon, "Can achievement differentials be explained by social class alone?" Ethnicities, vol. 7, no. 3, pp. 306-322, 2007.

[34] C. Kristen and N. Granato, "The educational attainment of the second generation in Germany: social origins and ethnic inequality," Ethnicities, vol. 7, no. 3, pp. 343-366, 2007.

[35] C. Kristen and N. Granato, "Bildungsinvestitionen in Migrantenfamilien," in Migration-Integration-Bildung. Grundfragen und Problembereiche. IMIS-Beiträge Heft 4/2004, K. J. Bade and M. Bommes, Eds., pp. 123-142, University Osnabrück, Osnabrück, Germany, 2004.

[36] A. G. Müller and P. Stanat, "Schulischer Erfolg von Schülerinnen und Schülern mit Migrationshintergrund. Analysen zur Situation von Zuwanderern aus der ehemaligen Sowjetunion und aus der Türkei," in Herkunftsbedingte Disparitäten im Bildungswesen. Vertiefende Analysen im Rahmen von PISA 2000, J. Baumert, P. Stanat, and R. Watermann, Eds., pp. 221-255, VS Verlag für Sozialwissenschaften, Wiesbaden, Germany, 2006.

[37] R. Erikson and J. O. Jonsson, "Explaining class inequality in education: the swedish test case," in Can Education Be Equalized? The Swedish Case in Comparative Perspective, R. Erikson and J. O. Jonsson, Eds., pp. 1-63, Westview Press, Stockholm, Sweden, 1996.

[38] D. S. Massey, M. Mooney, K. C. Torres, and C. Z. Charles, "Black immigrants and black natives attending selective colleges and universities in the United States," American Journal of Education, vol. 113, no. 2, pp. 243-271, 2007.

[39] R. M. Friedberg, "You can't take it with you? Immigrant assimilation and the portability of human capital," Journal of Labor Economics, vol. 18, no. 2, pp. 221-251, 2000.

[40] C. Kristen, "Ethnische Diskriminierung im deutschen Bildungssystem. Theoretische Überlegungen und empirische Ergebnisse," Tech. Rep., Wissenschaftszentrum, Berlin, Germany, 2006.

[41] A. J. Fuligni, "The academic achievement of adolescents from immigrant families: the roles of family background, attitudes, and behavior," Child Development, vol. 68, no. 2, pp. 351-363, 1997.

[42] J. E. Glick and M. J. White, "Post-secondary school participation of immigrant and native youth: the role of familial resources and educational expectations," Social Science Research, vol. 33, no. 2, pp. 272-299, 2004.

[43] L.-A. Vallet and J.-P. Caille, "Migration and integration in France. Academic careers of immigrants' children in lower and upper secondary school," in Proceedings of the European Societies or European Society? Migrations and Inter-Ethnic Relations in Europe, Obernai, France, September 1999.

[44] C. Kristen, School choice and ethnic school segregation. Primary school selection in Germany, Waxmann, Münster, Germany, 2005.

[45] A. Heath and Y. Brinbaum, "Guest editorial: explaining ethnic inequalities in educational attainment," Ethnicities, vol. 7, no. 3, pp. 291-304, 2007. 
[46] D. J. Condron, "Social class, school and non-school environments, and black/white inequalities in children's learning," American Sociological Review, vol. 74, no. 5, pp. 683-708, 2009.

[47] H. Esser, "Familienmigration, Schulsituation und interethnische Beziehungen," Zeitschrift für Pädadogik, vol. 3, pp. 317-336, 1989.

[48] H. Esser, "Kulturelle Pluralisierung und strukturelle Assimilation: das Problem der ethnischen Schichtung," Schweizerische Zeitschrift für Politikwissenschaft, vol. 7, pp. 97-108, 2001.

[49] K. Westerbeek, The colours of my classroom. A study into the effects of the ethnic composition of classrooms on achievement of pupils from different ethnic backgrounds, Ph.D. thesis, European University Institute, Florence, Italy, 1999.

[50] P. Stanat, "Schulleistungen von Jugendlichen mit Migrationshintergrund: die Rolle der Zusammensetzung der Schülerschaft," in Herkunftsbedingte Disparitäten im Bildungswesen. Vertiefende Analysen im Rahmen von PISA 2000, J. Baumert, P. Stanat, and R. Watermann, Eds., pp. 189-220, VS Verlag, Wiesbaden, Germany, 2006.

[51] A. Portes and L. Hao, "The schooling of children of immigrants: contextual effects on the educational attainment of the second generation," Proceedings of the National Academy of Sciences of the United States of America, vol. 101, no. 33, pp. 11920-11927, 2004.

[52] F.-O. Radke, "Die Illusion der meritokratischen Schule. Lokale Konstellationen der Produktion von Ungleichheit im Erziehungssystem," in Migration-Integration-Bildung. Grundfragen und Problembereiche. IMIS-Beiträge Heft 4/2004, K. J. Bade and M. Bommes, Eds., pp. 143-178, University Osnabrück, Osnabrück, Germany, 2004.

[53] J. W. Schofield, "Migrationshintergrund, Minderheitenzugehörigkeit und Bildungserfolg. Forschungsergebnisse der pädagogischen, Entwicklungs- und Sozialpsychologie," AKIForschungsbilanz 5, 2006, http://www.wzb.eu/ZKD/AKI/ publications.de.htm.

[54] D. J. Condron, "An early start. Effects of ability grouping in reading achievement," in Proceedings of the Annual Meeting of the American Sociological Association, Atlanta Hilton Hotel, Atlanta, Ga, USA, 2010.

[55] M. Jungbauer-Gans, H. Lohmann, and C. K. Spieß, Bildungsungleichhheiten und Privatschulen in Deutschland, 2011.

[56] S. T. Fiske and S. E. Taylor, Social Cognition. From Brains to Culture, McGraw-Hill, New York, NY, USA, 2008.

[57] L. Pendry, "Soziale Kognition," in Sozialpsychologie (5., vollst. überarb. Aufl.), K. Jonas, W. Stroebe, and M. Hewstone, Eds., pp. 111-145, Springer Medizin, Heidelberg, Germany, 2007.

[58] L.-E. Petersen and B. Six, Stereotype, Vorurteile und soziale Diskriminierung. Theorien, Befunde und Interventionen, Beltz PVU, Weinheim, Germany, 2008.

[59] J. Aronson and C. M. Steele, "Stereotypes and the fragility of academic competence, mo-tivation, and self-concept," in Handbook of Competence and Motivation, A. J. Elliot and C. S. Dweck, Eds., pp. 436-460, Guilford, New York, NY, USA, 2005.

[60] B. E. Blaine, Understanding the Psychology of Diversity, Sage, Los Angeles, Calif, USA, 2007.

[61] J. E. Farley, Majority-Minority Relations, Upper Saddle River, New Jersey, NJ, USA, 2005.

[62] F. Heckmann, Education and the integration of migrants. Challenges for European Education Systems Arising from
Migration and Strategies for the Successful Integration of Migrant Children in European Schools and Societies. NESSE Analytical Report 1 for EU Commission DG Education and Culture, 2008, http://www.efms.uni-bamberg.de/pdf/NESEducationIntegrationMigrants.pdf.

[63] M. Levels, G. Kraaykamp, and J. Dronkers, "Immigrant children's educational achievement in western countries: origin, destination, and community effects on mathematical performance," American Sociological Review, vol. 73, no. 5, pp. 835-853, 2008.

[64] D. H. Krymkowski, "The process of status attainment among men in Poland, the U.S., and West Germany," American Sociological Review, vol. 56, pp. 46-59, 1991.

[65] M. Jungbauer-Gans, "Einfluss des sozialen und kulturellen Kapitals auf die Lesekompetenz. Ein Vergleich der PISA 2000-Daten aus Deutschland, Frankreich und der Schweiz," Zeitschrift für Soziologie, vol. 33, no. 5, pp. 375-397, 2004.

[66] J. S. Coleman and T. Hoffer, Public and private high schools. The impact of communities, Basic Books, New York, NY, USA, 1987.

[67] J. S. Coleman, Equality and Achievement in Education, Westview Press, Boulder, Colo, USA, 1990.

[68] M. Paunescu, "Ineffizienzen privater und öffentlicher Schulen im internationalen Vergleich-eine Data-EnvelopmentAnalyse der PISA-2000-daten," in Bildungsökonomische Analysen mit Mikrodaten. IAB, BeitrAB 295, L. Bellmann and D. Sadowski, Eds., pp. 25-60, Institut für Arbeitsmarkt- und Berufsforschung, Nürnberg, Germany, 2005.

[69] J. Dronkers, "More parental choice in Europe? Overview of effectiveness differences between religious schools and public schools in several European societies," in Proceedings of the Annual Meeting of the American Educational Research Association, vol. 2001, Seattle Wash, April 2001.

[70] J. Dronkers and P. Robert, The Effectiveness of Public and Private Schools from a Comparative Perspective, European University Institute, Florence, Italy, 2003.

[71] J. Dronkers and S. Avram, "A cross-national analysis of the relations of school choice and effectiveness differences between private-dependent and public schools," Educational Research and Evaluation, vol. 16, no. 2, pp. 151-175, 2010.

[72] H. Lohmann, C. K. Spieß, and C. Feldhaus, "Der Trend zur Privatschule geht an bildungsfernen Eltern vorbei," DIW Wochenbericht, vol. 76, pp. 640-646, 2009.

[73] J. R. Betts and R. W. Fairlie, "Explaining ethnic, racial, and immigrant differences in private school attendance," Journal of Urban Economics, vol. 50, no. 1, pp. 26-51, 2001.

[74] J. R. Betts and R. W. Fairlie, "Does immigration induce 'native flight' from public schools into private schools?" Journal of Public Economics, vol. 87, no. 5-6, pp. 987-1012, 2003.

[75] S. L. Morgan and A. B. Sørensen, "Parental networks, social closure, and mathematics learning: a test of coleman's social capital explanation of school effects," American Sociological Review, vol. 64, no. 5, pp. 661-681, 1999.

[76] J. E. Chubb and T. M. Moe, "Politics, markets, and the organization of schools," in Education, Culture, Economy, Society, A. H. Halsey et al., Ed., vol. 82, pp. 1065-1087, Oxford University Press, New York, NY, USA, 1997.

[77] J. Dronkers and P. Robert, "School choice in the light of the effectiveness differences of various types of public and private schools in 19 OECD countries," Journal of School Choice, vol. 2, no. 3, pp. 260-301, 2008. 
[78] J. Dronkers and P. Robert, "Differences in scholastic achievement of public, private government-dependent, and private independent schools: a cross-national analysis," Educational Policy, vol. 22, no. 4, pp. 541-577, 2008.

[79] V. Vandenberghe, "Private government-dependent and public schools. An international effectiveness analysis," Public Economics 0308002, EconWPA, 2003, http://129.3.20.41/eps/ eps/pe/papers/0312/0312004.pdf.

[80] T. Fuchs and L. Wößmann, "What accounts for international differences in student performance? A re-examination using PISA data," Tech. Rep. 1235, CESifo, Munich, Germany, 2004.

[81] L. Wößmann, "Ursachenkomplexe der PISA-Ergebnisse. Untersuchungen auf Basis der internationalen Mikrodaten," Tech. Rep. 16, Ifo, Frankfurt, Germany, 2005.

[82] UNDP. Human development report, 2007 http://hdr .undp.org/en/media/HDR_20072008_EN_Complete.pdf.

[83] V. Vandenberghe and S. Robin, "Evaluating the effectiveness of private education across countries: a comparison of methods," Labour Economics, vol. 11, no. 4, pp. 487-506, 2004.

[84] C. Standfest, O. Köller, A. Scheunpflug, and M. Weiß, "Profil und Erträge von evangelischen und katholischen Schulen. Befunde aus sekundäranalysen der PISA-Daten," Zeitschrift für Erziehungswissenschaften, vol. 7, pp. 359-379, 2004.

[85] M. Weiß and C. Preuschoff, "Schülerleistungen in staatlichen und privaten Schulen im Vergleich," in Die Institution Schule und die Lebenswelt der Schüler. Vertiefende Analysen der PISA-2000-Daten zum Kontext von Schülerleistungen, G. Schümer, K. J. Tillmann, and M. Weiß, Eds., pp. 39-71, VS Verlag, Wiesbaden, Germany, 2004.

[86] J. Dronkers, J. Baumert, and K. Schwippert, Are German non-public secondary schools more effective at teaching mathematics and natural science?, 1999, http://www .eui.eu/Personal/Dronkers/English/germanschoolsvalues.pdf.

[87] J. Dronkers and W. Hemsing, "Effektivität öffentlichen, kirchlichen und privaten Gymnasialunterrichts," Zeitschrift für Erziehungswissenschaft, vol. 2, pp. 247-249, 1999.

[88] D. N. Figlio and J. A. Stone, "Are private schools really better?" Research in Labor Economics, vol. 18, pp. 115-140, 1999.

[89] M. A. Somers, P. J. McEwan, and J. D. Willms, "How effective are private schools in Latin America?" Comparative Education Review, vol. 48, no. 1, pp. 48-169, 2004.

[90] B. S. Rangvid, Evaluating private school quality in Denmark, 2003, http://www.hha.dk/nat/WPER/03-2_bsr.pdf.

[91] R. Corten and J. Dronkers, "School achievement of pupils from the lower strata in public, private governmentdependent and private government-independent schools: a cross-national test of the Coleman-Hoffer thesis," Educational Research and Evaluation, vol. 12, no. 2, pp. 179-208, 2006.

[92] T. Modood, Capitals, ethnic identity and educational qualifications, 2004, http://www.bristol.ac.uk/sociology/leverhulme/cultural_trends_capitals.pdf.

[93] P. R. Bennett and A. Lutz, "How african american is the net black advantage? Differences in college attendance among immigrant blacks, native blacks, and whites," Sociology of Education, vol. 82, no. 1, pp. 70-100, 2009.

[94] T. Modood, "The number of ethnic minority students in British higher education: some grounds for optimism," Oxford Review of Education, vol. 19, pp. 167-182, 1993.
[95] J. Baumert, P. Stanat, and A. Demmrich, "PISA 2000: Untersuchungsgegenstand, theoretische Grundlagen und Durchführung der Studie," in Deutsches PISA-Konsortium (Hrsg.). PISA 2000. Basiskompetenzen von Schülerinnen und Schülern im internationalen Vergleich, pp. 15-68, Leske + Budrich, Opladen, Germany, 2001.

[96] H. Sibberns and J. Baumert, "Anhang A, 1. Stichprobenziehung und Stichprobengewichtung," in Deutsches PISAKonsortium. PISA 2000. Basiskompetenzen von Schülerinnen und Schülern im internationalen Vergleich, pp. 511-517, Leske + Budrich, Opladen, Germany, 2001.

[97] C. H. Carstensen, A. Frey, O. Walter, and S. Knoll, "Technische Grundlagen des dritten internationalen Vergleichs," in PISA 2006. Die Ergebnisse der dritten internationalen Vergleichsstudie, M. Prenzel, C. Artelt, J. Baumert et al., Eds., pp. 367-390, Waxmann, Münster, Germany, 2007.

[98] O. Köller, R. Watermann, and J. Baumert, "Anhang A, 2. Skalierung der Leistungstests in PISA. Pp. 517-524 in Deutsches PISA-Konsortium," in PISA 2000. Basiskompetenzen von Schülerinnen und Schülern im internationalen Vergleich, Leske + Budrich, Opladen, Germany, 2001.

[99] OECD. Manual for the PISA 2000 International Database, 2003, http://www.pisa.oecd.org/.

[100] R. Adams and M. Wu, "Organization for economic cooperation and development," Tech. Rep., PISA, 2003.

[101] CIA. The World Fact Book, 2010, https://www.cia.gov/ library/publications/the-world-factbook/.

[102] Statistics Iceland, 2010, http://www.statice.is/.

[103] UNDP Azerbaijan. Azerbaijan human development report, 2007, http://hdr.undp.org/en/reports/nationalreports/ europethecis/azerbaijan/nhdr2007gendereng.pdf.

[104] UNDP Indonesia, Indonesia human development report, 2004, http://hdr.undp.org/en/reports/nationalreports/asiathepacific/indonesia/indonesia_2004_en.pdf.

[105] UNDP Jordan, Jordan human development report, 2004, http://hdr.undp.org/en/reports/nationalreports/arabstates/ jordan/jordan_2004_en.pdf.

[106] UNDP Montenegro, National human development report, 2009, http://hdr.undp.org/en/reports/nationalreports/ europethecis/montenegro/Montenegro_NHDR_2009_EN .pdf.

[107] UNDP Serbia, Human development report Serbia, 2008, http://hdr.undp.org/en/reports/nationalreports/europeethecis/serbia/Serbia_nhdr2008_eng.pdf.

[108] H. E. Klein, Privatschulen in Deutschland. RegulierungFinanzierung-Wettbewerb. Forschungsberichte aus dem Institut der deutschen Wirtschaft Köln Nr. 25. Köln: deutscher Institutsverlag.

[109] OECD. Student enrolled by type of institution, 2006, http://stats.oecd.org/wbos/Index.aspx?DatasetCode=RENRL.

[110] P. Stanat and M. Kunter, "Geschlechtsunterschiede in Basiskompetenzen," in Deutsches PISA-Konsortium. PISA 2000. Basiskompetenzen von Schülerinnen und Schülern im internationalen Vergleich, pp. 251-270, Leske + Budrich, Opladen, Germany, 2001.

[111] R. Boudon, Education, Opportunity, and Social Inequality, John Wiley \& Sons, New York, NY, USA, 1974.

[112] H. B. G. Ganzeboom and D. J. Treiman, "Internationally comparable measures of occupational status for the 1988 International Standard Classification of Occupations," Social Science Research, vol. 25, no. 3, pp. 201-239, 1996. 
[113] P. Bourdieu, "Ökonomisches Kapital, kulturelles Kapital, soziales Kapital," in Soziale Ungleichheiten. Sonderband der Kölner Zeitschrift für Soziologie und Sozialpsychologie, R. Kreckel, Ed., pp. 183-198, Schwartz, Göttingen, Germany, 1983.

[114] T. J. Madigan, "Cultural capital," in Education and sociology. An Encyclopedia, D. L. Levinson, P. W. Cookson, and A. R. Sadovnik, Eds., pp. 121-124, Routledge, New York, NY, USA, 2002.

[115] P. DiMaggio, "Cultural capital and school success: the impact of status culture participation on the grades of U.S. high school students," American Sociological Review, vol. 47, pp. 189-201, 1982.

[116] A. Lareau and E. B. Weininger, "Cultural capital in educational research: a critical assessment," Theory and Society, vol. 32, no. 5-6, pp. 567-606, 2003.

[117] P. DiMaggio and J. Mohr, "Cultural capital, educational attainment, and marital selection," American Journal of Sociology, vol. 90, pp. 1231-1261, 1985.

[118] V. J. Roscigno and J. W. Ainsworth-Darnell, "Race, cultural capital, and educational resources: persistent inequalities and achievement returns," Sociology of Education, vol. 72, no. 3, pp. 158-178, 1999.

[119] P. M. DeGraaf, "Parents' financial and cultural resources. Grades, and transition to secondary school in the Federal Republic of Germany," European Sociological Review, vol. 4, pp. 209-221, 1988.

[120] N. D. De Graaf, P. M. De Graaf, and G. Kraaykamp, "Parental cultural capital and educational attainment in the Netherlands: a refinement of the cultural capital perspective," Sociology of Education, vol. 73, no. 2, pp. 92-111, 2000.

[121] T. A. B. Snijders and R. J. Bosker, Multilevel analysis. An introduction to basic and advanced multilevel modeling, Sage, New Delhi, India, 1999.

[122] T. A. B. Snijders, "Fixed and random effects," in Encyclopedia of Statistics in Behavioral Science, B. S. Everitt and D. C. Howell, Eds., pp. 664-665, John Wiley \& Sons, Chichester, UK, 2005.

[123] S. W. Raudenbush and A. S. Bryk, Hierarchical Linear Models. Applications and Data Analysis Methods, Sage, New Delhi, India, 2nd edition, 2002.

[124] S. Raudenbush, A. Bryk, Y. F. Cheong, R. Congdon, and M. du Toit, HLM 6. Hier-Archical Linear \& Nonlinear Modeling, Scientific Software International, Lincolnwood, Ill, USA, 2004.

[125] S. Rabe-Hesketh and A. Skrondal, Multilevel and Longitudinal Modeling Using Stata, Stata Press, College Station, Tex, USA, 2nd edition, 2008.

[126] J. L. Schafer and J. W. Graham, "Missing data: our view of the state of the art," Psychological Methods, vol. 7, no. 2, pp. 147-177, 2002.

[127] R. J. A. Little and D. B. Rubin, Statistical Analysis with Missing Data, Wiley-Interscience, Hoboken, NJ, USA, 2nd edition, 2002.

[128] D. B. Rubin, Multiple Imputation for Nonresponse in Surveys, John Wiley \& Sons, New York, NY, USA, 1987.

[129] P. Royston, ICE: multiple imputation of missing values. UCLA: academic Technol-ogy Services, Statistical Consulting Group, 2004, http://www.ats.ucla.edu/stat/stata/ado/analysis/.

[130] A. Janßen and J. H. Schroedter, "Kleinräumliche Segregation der ausländischen Bevölkerung in Deutschland: eine Analyse auf der Basis des Mikrozensus," Zeitschrift für Soziologie, vol. 36, no. 6, pp. 453-472, 2007. 


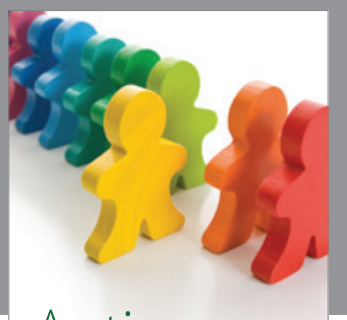

Autism

Research and Treatment
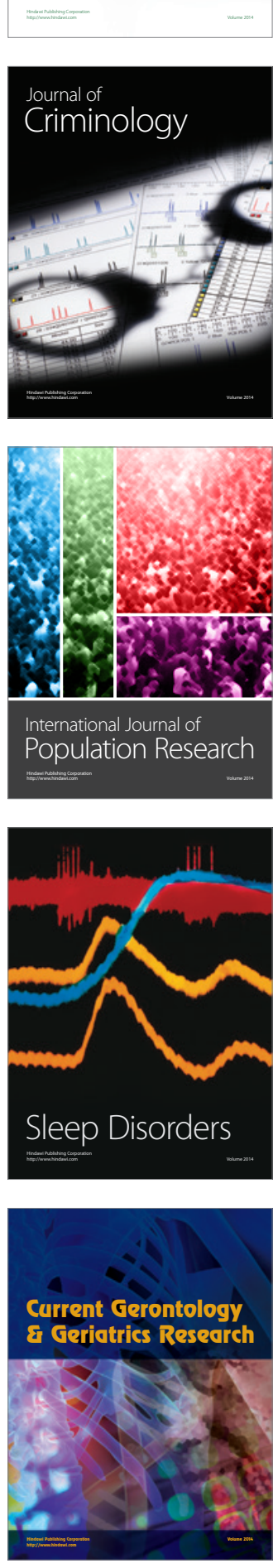
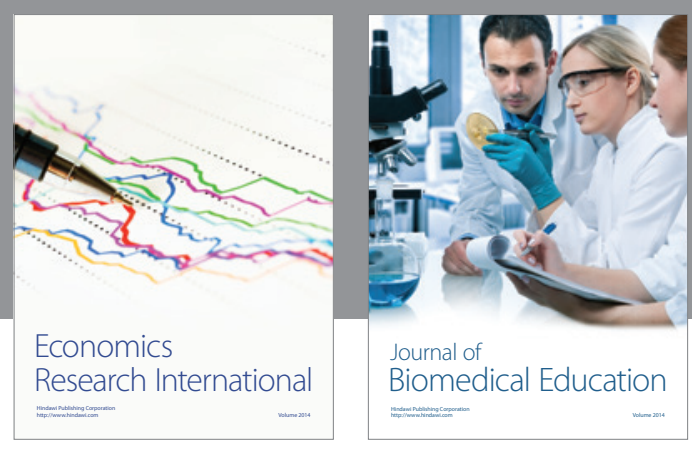

Journal of

Biomedical Education

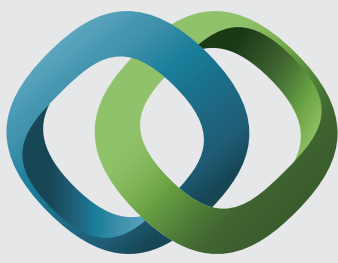

\section{Hindawi}

Submit your manuscripts at

http://www.hindawi.com
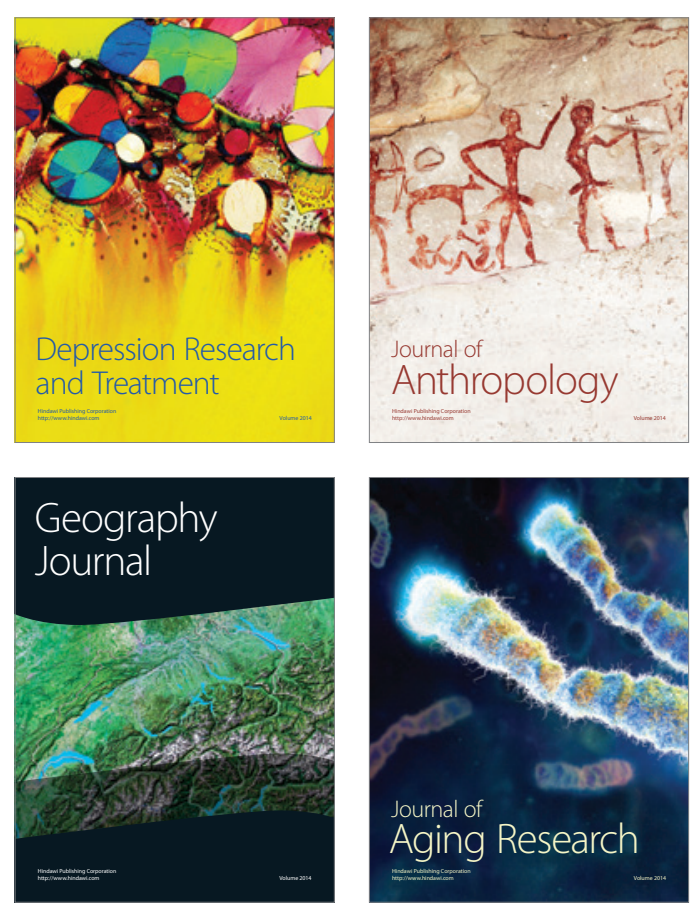

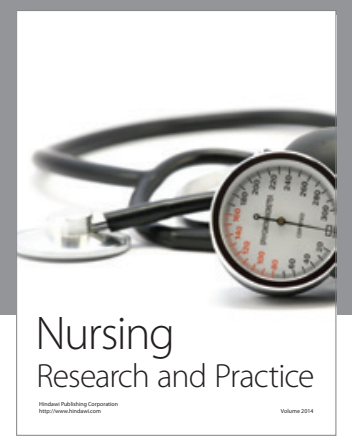

Nursing

Research and Practice

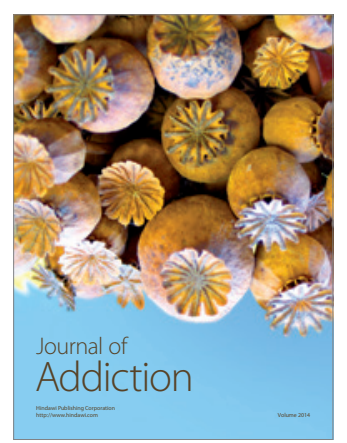

Child Development

Research

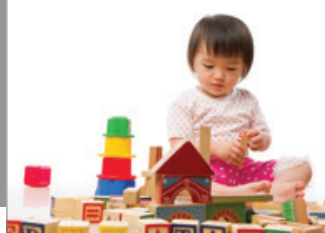

迥
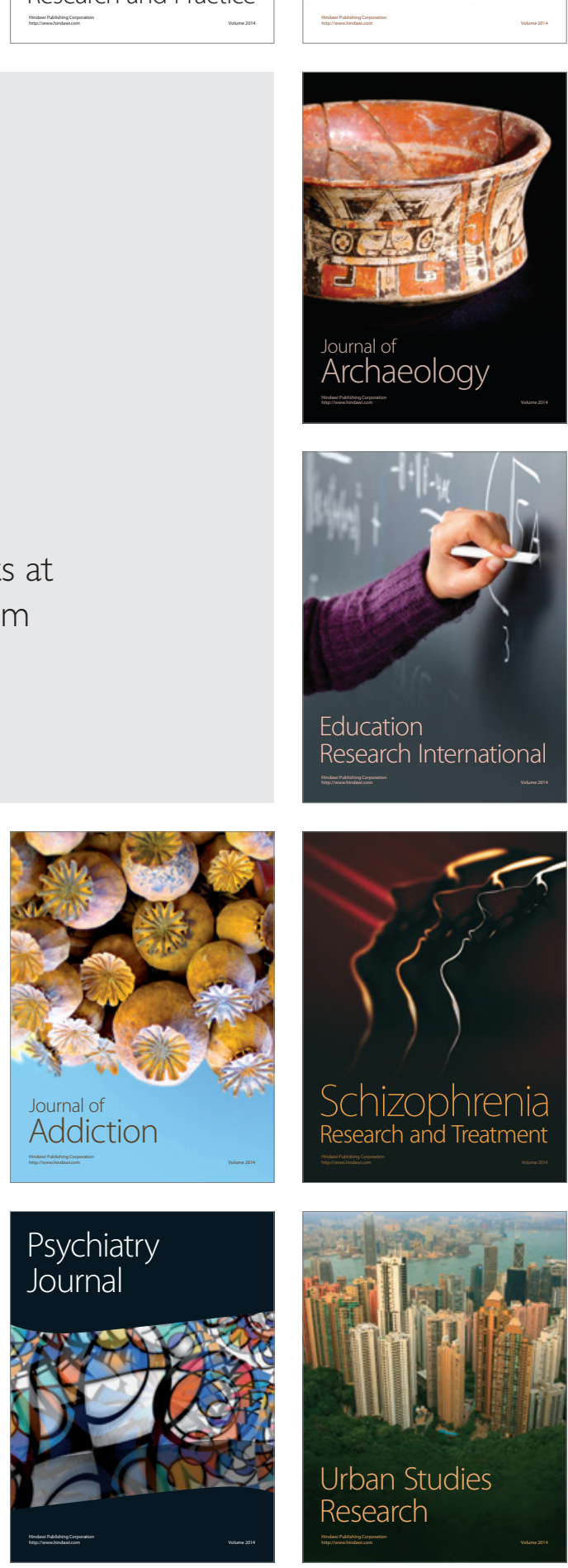